\title{
The 1954 Convention Relating to the Status of Stateless Persons: Implementation Within the European Union Member States and Recommendations for Harmonization
}

\author{
Carol Batchelor
}

\begin{abstract}
This article provides an assessment of the implementation of the 1954 Convention relating to the Status of Stateless Persons as of 2003 within the fifteen European Union Member States. The study provides a brief overview of the history, object, and purpose of the 1954 Convention, analyzing the definition of statelessness and methods for practical implementation. Approaches taken by EU Member States to the identification and recognition of stateless persons on their respective territories are assessed, and recommendations aimed at furthering harmonization of approaches as between States are outlined.
\end{abstract}

\section{Résumé}

Cet article propose une évaluation de la mise en application de la Convention de 1954 relative au statut des apatrides à la date de 2003 dans les 15 États membres de l'Union Européenne. L'étude fait un bref survol de l'historique de la Convention de 1954, de son contenu et de son objectif, analysant la définition de l'apatridie et des façons d'appliquer la convention dans la pratique. Elle évalue les approche adoptées pas les divers États membres de l'Union Européenne pour l'identification et la reconnaissance des personnes apatrides sur leur territoires respectifs et fait des recommandations pour harmoniser les approches entre Etats.

\section{Executive Summary}

T $T^{\text {ithin the European Union, thirteen of the fifteen }}$ $\sqrt{ }$ current Member States are party to the 1954

Convention relating to the Status of Stateless Persons. Therefore, there is a potential legal framework within the EU for identifying cases of statelessness and for furthering appropriate solutions at the national level which are compatible with EU policy and legal principles. This study has been undertaken to provide an overview of the tools and mechanisms in place, or needed, to promote the implementation of the 1954 Convention within EU Member States and to outline any additional steps recommended for harmonization.

The study provides a brief overview of the history, object, and purpose of the 1954 Convention. Article 1 defining a stateless person is analyzed and methods for practical implementation considered. The study reviews the approaches taken by EU Member States to the identification and recognition of stateless persons on their respective territories. The implications of recognizing someone as stateless, and the approaches taken by various EU Member States to providing access to the rights outlined in the Convention, are assessed. Recommendations concerning implementation of the 1954 Convention within Member States aimed also at furthering harmonization of approaches as between States are outlined below.

The 1954 Convention attempts to resolve the legal void in which the stateless person often exists, by identifying the problem of statelessness, promoting the acquisition of a legal identity, and providing for a legal status which will serve as a basis for access to basic social and economic rights. The Convention is the primary international instru- 
ment adopted to date to regulate and improve the legal status of stateless persons and to ensure to stateless persons fundamental rights and freedoms without discrimination. For those persons who are stateless refugees, who have a well-founded fear of persecution, the 1951 Convention and related legal regime is the relevant reference point. The 1954 Convention was adopted to cover those stateless persons who are not refugees and who are not, therefore, covered by the 1951 Refugee Convention.

UNHCR has a particular role to play concerning statelessness. The Office advocates globally for enhanced co-operation between States to assess situations of statelessness and to further appropriate solutions aimed at ensuring that all stateless persons have a legal status. Over the past decade, UNHCR has expanded its activities worldwide to work with States toward the prevention and reduction of statelessness. Problems continue to persist, nevertheless, and until international efforts result in the abolishment of statelessness, persons affected should have access to procedures designed to identify their particular problem of statelessness, to documentation and a legal identity, and to a minimum standard of rights to ensure their security. It is against this backdrop that the 1954 Convention is highly relevant in Europe today.

The 1954 Convention provides the internationally recognized definition of a stateless person in Article 1 of the instrument. This is the basis on which States can determine at the national level to whom the Convention will apply. It is also an appropriate basis for harmonization of approaches as between States by providing a common reference point defining statelessness. Each State Party determines through its own procedures whether a person fits the definition of a stateless person outlined in Article 1. Clearly, the first criterion for application of the Convention to an individual is that the person is found by the State concerned to be stateless.

As concerns the recognition of stateless persons and the approach to solutions, practice in the EU varies, with very few of the Member States possessing a specialized procedure dedicated to examining an applicant's claim of statelessness. If, however, States do not approach Article 1 with a common interpretation or application, it will be difficult to harmonize implementation of the Convention overall or, indeed, for decisions taken by one State party to be recognized as between States parties. This could mean that a single case will arrive at various results depending on the State in which the stateless person lodges an application. As such, the lack of specialized procedures may be a compelling factor in pushing individuals from one jurisdiction to the next, or from one procedure to another within the same State. As one of the key objectives of the 1954 Convention is to promote the acquisition of a legal identity for a stateless person in one State, which will be widely recognized by other States, a lack of harmonized interpretation or implementation of Article 1 risks limiting the benefits of this instrument for both States and individuals concerned. The lack of specialized procedures also makes it impossible to determine the magnitude of the problem of statelessness within EU Member States, as there may be many cases of statelessness which go unnoticed or unidentified.

The possibility, in appropriate cases, for a stateless person to secure residence is of particular importance given that it is essentially through this that the individual will be able to access the full rights and benefits provided for in the 1954 Convention. In European Union Member States, rights and benefits available to stateless persons are often attached to the type of residence permit granted. Those granted leave to remain on humanitarian grounds may receive rights equivalent to those of recognized refugees. In other States, economic and social rights may not be granted to persons permitted to stay on humanitarian grounds or under temporary leave to remain. Family reunification rights may vary depending on the type of stay granted.

Many of the social and economic benefits outlined in the Convention are provided for within the national legal systems of EU Member States, although they may be tied to grant of a residence permit. Once a foreigner has residence in an EU Member State, social and economic rights are similar to those for nationals of the Member State concerned, although certain distinctions may be found such as the extent of social welfare. Certain rights may also be linked to the grant of permanent rather than temporary residence. It must be noted, however, that there is no common EU approach to the determination of statelessness under Article 1 of the 1954 Convention. Consequently, there is a lack of harmonization specific to recognized stateless persons of the remaining provisions of the 1954 Convention. Therefore, variations between States will inevitably arise with regard to who is considered stateless as well as in responses adopted to address statelessness. Moreover, under certain provisions of the 1954 Convention, recognition within one State is expected to give rise to entitlements in all other Contracting Parties. However, without harmonization of approaches, discrepancies in the implementation of these entitlements and, therefore, regulation of the movement of persons between Member States are also possible.

For purposes of this study, a key objective was to analyze the tools and mechanisms in place to address issues of statelessness. Without the tool or mechanism in place to identify and recognize stateless persons specifically with regard to their statelessness, the remaining provisions of the 
Convention will be available to stateless persons only insofar as they are available to populations generally. The lack of a framework specific to stateless persons is, in fact, a key finding of the study and the basis on which recommendations have been elaborated. Nonetheless, there are various best practices noted at the national level which could guide on approaches to harmonization between Member States. These have served as a backdrop to the recommendations outlined below.

\section{Recommendations}

- States are encouraged to adopt a designated procedure under Article 1 of the 1954 Convention, designed to facilitate access to the statelessness determination process and to identify stateless persons.

- In facilitating solutions, States are encouraged to adopt legislation regulating the transit or entry, as well as the rights and duties, of recognized stateless persons.

- Specialized units with dedicated decision makers are needed as an integral aspect of application of the 1954 Convention. States, in co-operation with UNHCR, are invited to introduce specialized training and to disseminate guidelines on the implementation of the 1954 Convention and on identification of stateless persons.

- As far as possible, States should ensure information exchange, legal assistance, translation services, and other administrative support to facilitate procedures, including personal interviews with the applicant where applicable.

- Decision-making authorities are encouraged to adopt collaborative approaches in receiving and analyzing relevant information as it pertains to the determination of an individual's claim concerning statelessness.

- States are invited to introduce mechanisms to promote the acquisition of lawful stay, in appropriate cases, for recognized stateless persons, in particular for those who have no alternate option. Consultations concerning the type of procedure and status granted by each EU Member State should be promoted with a view to harmonization.

- Efforts should be made to facilitate the documentation of stateless persons, to issue the Convention Travel Document where appropriate, and to establish procedures for the recognition of such documentation as between EU Member States.

- In cases where readmission agreements are concluded, States should pay particular regard to ensuring a legal status is secured for stateless persons in the country concerned.

- Efforts should be made to harmonize approaches to those specific provisions of the 1954 Convention which stipulate treatment equal to that of national in the State of habitual residence as well as in other EU Member States.
- UNHCR and States are invited to enhance co-operation and exchange of information concerning the determination of statelessness and with regard to the most appropriate solutions.

- Those EU Member States which have not yet acceded to the 1954 Convention are encouraged to give renewed consideration to early ratification of this instrument.

\section{Introduction}

In recent years, statelessness has arisen in a number of contexts within Europe. In some instances, statelessness has been associated with displacement and has overlapped with refugee flows. Statelessness issues have been relevant to conflict prevention and to post-conflict resolution. Significant challenges arose in the context of the succession of States and the determination of nationality ${ }^{1}$ status within States emerging from dissolution. Equally, States regaining independence were faced with how to address nationality questions arising on their territory. Events such as these impact not only the State concerned, but also States to which individuals might travel or with which persons have prior links.

While many States are diligent in ensuring persons born on their territories or born abroad to their nationals are not rendered stateless under national laws, problems of statelessness may still arise in the context of aliens entering or residing in their territories. In consultations with the European Union held under the Spanish Presidency in January of 2002, the Office of the United Nations High Commissioner for Refugees (UNHCR) outlined the problem of statelessness in the context of the scope and content of international protection. Participants noted that the problem of statelessness has taken on new dimensions in the European context. ${ }^{2}$

Within the European Union, thirteen of the fifteen current Member States are party to the 1954 Convention relating to the Status of Stateless Persons. ${ }^{3}$ In principle, therefore, there is a legal framework within the EU for identifying cases of statelessness and for furthering appropriate solutions at the national level which are compatible with EU policy and legal principles. This study has been undertaken to provide an overview of the tools and mechanisms in place, or needed, to promote the implementation of the 1954 Convention within the current fifteen EU Member States and to outline any additional steps recommended for harmonization. ${ }^{4}$ The findings of the study will, moreover, be relevant for purposes of harmonization of approaches within future Member States as well.

The study provides a brief overview of the history, object, and purpose of the 1954 Convention, shedding light on how the instrument should be interpreted and applied. An 
analysis of Article 1 defining a stateless person is outlined with methods for practical implementation considered. The study reviews the varied approaches taken by EU Member States to the identification and recognition of stateless persons on their respective territories. The implications of recognizing someone as stateless and the approaches taken by various EU Member States on providing access to the rights outlined in the Convention are considered. Recommendations to support the full implementation of the 1954 Convention within each Member State, and to promote harmonization of approaches as between States, have been outlined.

The project has been funded with support from the European Commission. Collaboration with partners, such as the European Commission, in promoting implementation of the 1954 Convention within the EU will help to address particular problems faced by stateless persons and to reduce such cases.

\section{A. History of the 1954 Convention}

In 1948, the Economic and Social Council of the United Nations requested the Secretary General to undertake a study and to make recommendations on the situation of stateless persons. ${ }^{5}$ This study led to the formation of an $\mathrm{Ad}$ Hoc Committee on Statelessness and Related Problems considering, inter alia, the desirability of a revised convention relating to the status of refugees and stateless persons. ${ }^{6}$ In February 1950, the Ad Hoc Committee completed its work with the adoption of a Draft Convention relating to the Status of Refugees and an accompanying Protocol relating to the Status of Stateless Persons.

Consequently, the United Nations General Assembly decided to convene a conference of plenipotentiaries, which adopted in 1951 the Convention relating to the Status of Refugees. ${ }^{7}$ The draft Protocol relating to the Status of Stateless Persons was not adopted at the Conference. Instead, it was communicated by the UN Secretary General to governments with the request that they comment on those aspects of the 1951 Convention they would be prepared to extend to non-refugee stateless persons.

In 1954, after the 1951 Convention had already come into force, a new Conference of Plenipotentiaries was convened in New York to revise the Draft Protocol on the Status of Stateless Persons. During the Conference, however, the delegates decided to sever the Protocol from the 1951 Convention as it became clear that a separate instrument would be needed. ${ }^{8}$ The end result was the completion of a distinct Convention completely separate from the 1951 Convention, which was opened for signature on 28 September $1954 .{ }^{9}$

The overlap between problems of statelessness and refugee flows was considered substantial in post-war Europe, requiring preparation of a legal framework designed to address both problems. Yet not all stateless persons actually become refugees or necessarily cross borders. Moreover, States have well-established approaches to the determination of nationality which, while not problematic internally, may inadvertently collide with the established and equally legitimate approaches of another State. Hence, some cases of statelessness arise as oversights or conflicts in legal approaches and are not the result of discrimination or deliberate denial of human rights. For such reasons, a comprehensive legal framework specifically tailored to the problem of statelessness was deemed necessary and, accordingly, was prepared under the auspices of the United Nations.

\section{B. Object and Purpose of the 1954 Convention}

The 1954 Convention attempts to resolve the legal void in which a stateless person often exists by identifying the problem of statelessness, promoting the acquisition of a legal identity, and providing, in appropriate cases, for residence which will serve as a basis for access to basic social and economic rights. The 1954 Convention relating to the Status of Stateless Persons is the primary international instrument adopted to date to regulate and improve the legal status of stateless persons and to ensure to them fundamental rights and freedoms without discrimination. For those persons who are stateless refugees, who have a well-founded fear of persecution, the 1951 Convention and related legal regime is the relevant reference point. ${ }^{10}$ The 1954 Convention was adopted to cover those stateless persons who are not refugees and who are not, therefore, covered by the Refugee Convention. ${ }^{11}$

The international community has long since seen the need to promote the avoidance and reduction of cases of statelessness, as aspects of conflict prevention, post-conflict resolution, and reduction of cases of displacement, and as part of the protection of the human rights of individuals. Article 15 of the 1948 Universal Declaration of Human Rights declares each person has an inherent right to a nationality. ${ }^{12}$ The challenge is in determining which nationality a person may have a right to. Mechanisms for the application of Article 15 were given concrete form by way of two international instruments concerning statelessness, the 1954 Convention relating to the Status of Stateless Persons and the 1961 Convention on the Reduction of Statelessness. ${ }^{13}$

These Conventions outline a comprehensive legal framework to avoid the creation of cases of statelessness (1961 Convention) and to ensure that, at a minimum, individuals are granted a legal status which provides them with a measure of stability and, in appropriate cases, normalizes their 
stay in a given country (1954 Convention). This, in turn, significantly decreases the potential for displacement. It also provides a reference point for resolving cases which might arise between States. In brief, the 1954 and 1961 Conventions provide a ready-made framework for addressing one of the consistent challenges to effective protection arising both in and between States. By seeking to ensure everyone has their right to a nationality in practice, this legal framework places emphasis on securing national protection for persons who might otherwise be in need of international protection. It must be noted that if all States actively applied the provisions of the 1961 Convention, there would be a decrease in the number of cases arising in relation to the 1954 Convention. ${ }^{14}$ In this regard, comprehensive efforts to promote the avoidance of statelessness altogether will necessarily be coupled with increased efforts to secure and protect a nationality for all persons through the effective application of nationality laws globally. ${ }^{15}$

\section{UNHCR's Role Concerning Statelessness}

UNHCR has been requested to undertake specific activities to assist States in avoiding and reducing cases of statelessness globally. ${ }^{16}$ In 1974, the United Nations General Assembly requested UNHCR to assume temporarily the responsibilities foreseen in Article 11 of the 1961 Convention, of a body to which a person claiming the benefit of the Convention may apply for the examination of his claim and for assistance in presenting it to the appropriate authority. ${ }^{17}$ In 1976, this role was renewed and extended indefinitely. ${ }^{18}$

In 1995, UNHCR's Executive Committee in its Conclusion No. 78 on statelessness requested UNHCR to promote accession to the 1954 and 1961 Statelessness Conventions and to provide technical and advisory services pertaining to the preparation and implementation of nationality legislation to interested States. ${ }^{19}$

UNHCR advocates globally for enhanced co-operation between States, in consultation with other concerned organizations and civil society, to assess situations of statelessness and to further appropriate solutions aimed at ensuring that all stateless persons have a legal status. Increased accessions to and implementation of the Statelessness Conventions will help to address the particular problems faced by stateless persons and to reduce such cases.

While progress has been made in identifying cases of statelessness and in promoting appropriate solutions, numerous cases of statelessness continue, with new cases arising due to various factors such as: conflicts of laws between States; transfer of territory; laws relating to civil status and marriage; administrative practices; discrimination and denationalization; lack of registration or documentation of births and marriages; inheritance of statelessness; renuncia- tion or loss of nationality without the acquisition of an alternative nationality; and automatic loss due to residence abroad. ${ }^{20}$

Over the past decade, UNHCR has expanded its activities worldwide to work with States toward the prevention and reduction of statelessness. Problems continue to persist, nevertheless, and until international efforts result in the abolishment of statelessness, persons affected should have access to procedures designed to identify their particular problem of statelessness, access to documentation and a legal identity, and access to a minimum standard of rights to ensure their security. It is against this backdrop that the 1954 Convention is highly relevant in Europe today.

\section{Determining Statelessness}

The 1954 Convention provides the internationally recognized definition of a stateless person in Article 1 of the instrument. ${ }^{21}$ This is the basis on which States can determine at the national level to whom the Convention will apply. It is also the appropriate basis for harmonization of approaches as between States. Each State Party determines through its own procedures whether a person fits the definition of a stateless person outlined in Article 1. Clearly, the first criterion for application of the Convention to an individual is that the person is found by the State concerned to be stateless. ${ }^{22}$

If the person is found not to be stateless, the Convention will not be applicable. Existing State practice in the EU varies, with very few of the Member States possessing a specialized procedure dedicated to examining an applicant's claim of statelessness. If, however, States do not approach Article 1 with a common interpretation or application, it will be impossible to harmonize implementation of the Convention overall or, indeed, for decisions taken by one State party to be recognized as between States parties. This could mean that a single case will arrive at varying results depending on the State in which the stateless person makes an application. As one of the key objectives of the 1954 Convention is to promote the acquisition of a legal identity for a stateless person in one State which will be widely recognized by other States, a lack of harmonized interpretation or implementation of Article 1 risks limiting the benefits of this instrument for both States and individuals concerned.

\section{A. Definition of a Stateless Person}

The definition, set out in Article 1(1) provides that a stateless person is one "who is not considered as a national by any State under the operation of its law." This is the definition used at the international level and is incorporated into the nationality laws of many States. ${ }^{23}$ By indicating that a 
stateless person is someone who is not considered a national by any State under the operation of its law, the drafters refer to a legal bond between an individual and a State which is based on the internal laws of the State concerned. The Convention, thus, covers cases of de jure statelessness, as determined with reference to the internal law of relevant States. ${ }^{24}$ The Convention does not ask whether that nationality is effective, whether a person should or could be a national of a particular State based on its legislation, but rather whether the person is a national. ${ }^{25}$

A clear tenet of international law is that each State is sovereign in determining which persons are its nationals. ${ }^{26}$ In order to determine whether an individual is stateless, therefore, reference must be made to the internal law of each of the States in which an individual could have acquired a nationality. States generally attribute nationality at birth either to persons born on their territory (jus soli), or to persons born to their nationals regardless of place of birth (jus sanguinis). States normally incorporate at least one, although in some cases both, of these rules. Thus, in a typical situation, an individual will acquire a nationality at birth ex lege by descent or by being born in a particular country. Each nationality law will contain the provisions determining who automatically acquires nationality of that particular State at birth. States generally also allow foreigners to acquire nationality when certain conditions or links have been established, such as marriage to a national or continuous residence in the country. An individual, although born stateless, might acquire a nationality in this manner, that is, by naturalization.

Proving statelessness is like establishing a negative. The individual must demonstrate something that is not there. A person may fail to acquire a nationality at birth, or later in life lose nationality and become stateless through, for example, deprivation or renunciation of nationality or as a consequence of a territorial change. The former has been referred to as "original" or "absolute" statelessness, and the latter "subsequent" or "relative" statelessness. ${ }^{27}$ Regardless of the manner in which a person becomes stateless, the 1954 Convention definition would encompass all those who currently do not have the nationality of any State with reference to relevant laws. Moreover, the term "by operation of law" encompasses loss of nationality whether it occurs through the application of law or by an act of the executive authorities. ${ }^{28}$

In practice, UNHCR has noted the importance not only of reading another State's internal laws in assessing whether an individual might be stateless, but also of undertaking dialogue with the State concerned to determine how the laws are interpreted and how they are applied. For instance, the phrase "acquisition at birth" has fundamentally different meaning from one State to the next. It might refer to acquisition through jus soli in some States, and to acquisition through jus sanguinis in other States. It might also mean an automatic acquisition ex lege in some States, while in other States certain administrative procedures will be required without which the person concerned will not acquire the State's nationality. In yet other instances, the State itself may not consider the individual to actually fall within the target category defined by the law, but there will be no way to know this without confirmation of how that State interprets its laws.

The phrase "operation of law" must, therefore, be implemented within the context of international legal principles. Each State decides which persons are its nationals and, as not all States use the same approach, a reading of laws without further consultation can lead to findings of statelessness when a person actually is a national, or presumption of nationality when the person is actually stateless. The assessment of statelessness and the standard of proof are, therefore, pivotal concerns with which States are confronted during the examination of the application. It is necessary that the decision maker examine the internal law and its practical implementation in States where an apparent link exists to determine whether there is a legal bond of nationality. Relevant reference points could include any State in which the applicant previously held nationality, State of birth, the place(s) of previous habitual residence, States in which a parent held nationality, and States in which a spouse or children are nationals. ${ }^{29}$

It should also be noted that those who appear to be eligible for citizenship, but who must lodge an application, are generally not considered to be nationals "by operation of law" as the acquisition of nationality is not automatic but, rather, discretionary. Nationality granted on a discretionary basis by definition presumes that a State can grant its nationality, but can also reject the application. When discretion exists, only after the application has been approved and nationality conferred can the individual be considered a national of that State. ${ }^{30}$

\section{B. The Burden and Standard of Proof}

As noted, establishing statelessness is like proving a negative. Rather than proving that the legal bond exists with one particular country, establishing statelessness requires a demonstration of no legal bond with any relevant country. ${ }^{31}$ The drafters of the 1954 Convention were aware that difficulties might arise in establishing proof, and members of the conference anticipated extending "the benefits of the proposed instrument to as many persons as possible." 32

Documentary evidence from a responsible State authority certifying that the person concerned is not a national is normally a reliable form of evidence for purposes of estab- 
lishing statelessness. However, such documentary evidence will not always be available, in part precisely because States will not necessarily feel accountable for indicating which persons do not have a legal bond of nationality. The relevant authorities of the country of origin or former habitual residence may refuse to issue certified documentation that the applicant is not a national, or may not reply to inquiries. From a practical perspective, it might be assumed that if a State refuses to indicate that a person is a national, this itself is a form of evidence which could have a bearing on the claim because States normally extend diplomatic services and protection to their nationals. Nonetheless, in such cases, the State trying to determine statelessness under the Convention may need to review other types of evidence, including available documentation and reliable witnesses. ${ }^{33}$

If the definition in Article 1 were not to cover all instances in which the person involved actually lost or was deprived of nationality but has no official confirmation, the Convention would contain a discrimination against those persons whose claims to the status of a 'stateless person' is stronger than that of persons who gave up the protection freely - an alternative for which no basis exists. It must therefore be assumed that the definition contained in Article 1 covers, in substance, all persons who either never possessed or lost their nationality; the question of proof is to be adjusted to this intention. ${ }^{34}$

In establishing proof of statelessness, States should be prepared to: review the relevant legislation of States with which the individual has prior links; undertake consultations and request evidence from these States as needed; ${ }^{35}$ and request the full co-operation of the person concerned in providing all relevant facts and information. UNHCR can provide support in furthering consultations between States as appropriate, as well as technical information on the laws in various States globally.

\section{Exclusion}

Article 1(2) of the 1954 Convention defines persons who, despite falling within the scope of the definition contained in Article 1(1), and thus being stateless, will be excluded from the application of the Convention for particular reasons. There are three broad categories of persons to whom the Convention shall not apply despite the fact that they are stateless.

Article 1(2)(i) refers to those:

who are at present receiving from organs or agencies of the United Nations other than the United Nations High Commissioner for Refugees protection or assistance as long as they continue to receive such assistance.
This clause was drafted with, inter alia, the mandate of the United Nations Relief and Works Agency for Palestinian Refugees in the Near East (UNRWA) in mind. Created in 1949 to assist Palestinians displaced from the conflicts in Palestine from 1 June 1946 to 15 May 1948, UNRWA's mandate was later expanded to include Palestinians displaced from the Arab-Israeli conflict in 1967. ${ }^{36}$ UNRWA is the only UN agency relevant today to the exclusion envisaged under Article 1(2)(i) of the 1954 Convention.

Few jurisdictions within the European Union have interpreted Article 1(2)(i) of the 1954 Convention. The Federal Administrative Court in Germany has, by way of example, found that some Palestinians can receive the benefits of the 1954 Convention, while others are excluded if they themselves are directly responsible for the impossibility of their return to an UNRWA area. ${ }^{37}$ Nonetheless, the practice varies greatly, with several States within the European Union granting Palestinians different categories of stay on humanitarian grounds, without necessarily making a finding as to their nationality status or to possible exclusion under Article 1(2)(i). This is an area where States may benefit from reviewing approaches with an eye to harmonization.

The second provision leading to exclusion from the 1954 Convention is outlined in Article 1(2)(ii), covering:

persons who are recognised by the competent authorities of the country in which they have taken residence as having the rights and obligations which are attached to the possession of the nationality of that country.

The object and purpose of the Convention is to provide stateless persons with a legal identity and to secure, as far as possible, access to basic social and economic rights. If a stateless person has already secured legal residence in another State and is provided with rights greater than those provided for in the 1954 Convention overall, particularly full economic and social rights equivalent to those of a national and protection against deportation and expulsion, then there is no need to apply the Convention to that person. ${ }^{38}$ In principle, this provision would not apply unless the individual has the right to return and remain, or the State concerned is willing to reinstate these rights.

Moreover, the fact that someone may fall within a category of persons to whom such treatment could be extended does not mean that the person should necessarily be obliged to seek entry to that State if never previously resident there because the article is conditioned on having prior residence. Additionally, there may be instances in which it is inappropriate to require a person to seek entry to a State they have never previously been resident in and with which they have 
no specific connection. In cases where a person has established residence but is denied re-entry, this is a clear demonstration that any rights accorded are not equal to those attached to the possession of the nationality of that country. Each case will need to be assessed as to its particular facts to find the most appropriate solution.

Article 1(2)(iii) provides that the Convention shall not apply:

to persons with respect to whom there are serious reasons for considering that:

a. they have committed a crime against peace, a war crime, or a crime against humanity, as defined in international instruments drawn up to make provisions in respect of such crimes;

b. they have committed a serious non-political crime outside the country of their residence prior to their admission to that country;

c. they have been guilty of acts contrary to the purposes and principles of the United Nations.

All three crimes listed under subparagraph (a) are included in the statute of the International Criminal Court. Subparagraph (b) is intended to exclude persons who have committed egregious criminal acts in another jurisdiction, the seriousness of which must be weighed against a number of factors. Subparagraph (c) would include, for example, serious violations of the principles and purposes of the United Nations, often thought to be limited in application to persons closely linked with the highest authorities in a State or State-like entity. These clauses should be applied restrictively. The State will still be required to examine the case in light of the prohibition of refoulement contained in Article 3 of the European Convention for the Protection of Human Rights and Fundamental Freedoms (ECHR) ${ }^{39}$ and Article 3 of the Convention against Torture and Other Cruel, Inhuman or Degrading Treatment or Punishment (CAT).$^{40}$

\section{Termination of Statelessness Status}

There is only one durable solution to the problem of statelessness, and that is the acquisition of a nationality. The condition of being stateless will ipso facto terminate when one acquires a nationality. With regard to the status which is given to a stateless person under the 1954 Convention, and the fact that the majority of rights provided for flow from the grant of some form of legal stay, there may be circumstances when a State decides to withdraw or cancel the legal status the stateless person has in its territory. In Spain, for example, the statelessness status granted will cease automatically if:
- the stateless person has acquired Spanish nationality;

- the stateless person has been considered a national of another State or another State of fixed residence grants rights and obligations which are equivalent to the possession of the nationality of that State;

- another State has documented the person as stateless and granted permanent stay on its territory. ${ }^{41}$

This approach provides that in cases where a nationality has been acquired, the status of stateless will be removed as it is no longer needed. Likewise, in cases where an individual takes up residence in another State and either acquires nationality or is accorded a legal status and rights including permanent lawful stay, then the status of stateless will be removed in Spain as it is no longer needed. This framework ensures that in all other cases, the statelessness status is safeguarded. This is an area where harmonization of approaches between Member States of the European Union would prove useful, not least as it could help to ensure that persons who leave a State's territory temporarily, and who do not acquire such rights elsewhere, do not have their statelessness status inadvertently withdrawn. Harmonization would also assist in avoiding situations of multiple statuses in various States.

\section{Existing Legal Framework in EU Member States}

A. Determining Statelessness

Thirteen of the fifteen EU Member States are parties to the 1954 Convention. The definition of a stateless person found in Article 1(1) is, in principle, reflected in the legal framework of all of these States. Moreover, although Austria, for example, is not a State Party to the 1954 Convention, the Convention's definition of a stateless person is accepted as part of Austria's legal system. ${ }^{42}$ While there is largely a common reference point for defining a stateless person, the process of identifying persons who meet this definition varies significantly from State to State. An obstacle for some EU States may be the lack of implementing regulations or defined procedures.

In some Member States, the legal system permits the direct application of international instruments, while others have enacted ratification laws making the Convention part of the national law. ${ }^{43}$ In dualist systems, an incorporation law is necessary, which in some States has not yet been done. ${ }^{44}$ Regardless of the manner in which the Convention becomes part of the municipal legal order, it does not dictate the procedure for identifying an individual as stateless. Thus, to make it workable in a national structure, some form of implementing legislation setting up a recognition procedure will be necessary. Adopting legislation enabling a designated decision maker and guiding the manner in 
which to recognize a stateless person, as well as setting out the consequences of such recognition, is in the interests of both the Contracting State and the persons to whom the Convention might apply.

Some EU Member States, while lacking specific legislation establishing a procedure, nevertheless have an authority, either administrative or judicial, that has competence for recognizing that an individual is stateless. At present, Spain is the only country in the EU with a sub-legislative act dedicated to defining a procedure by which the designated authority may examine an application for recognition of stateless status. The Aliens' Law provides that the Minister of Interior will recognize as stateless those foreigners who meet the requirements of the 1954 Convention and grant status accordingly. The procedure for doing this is regulated by a Royal Decree. ${ }^{45}$

The implementing decree foresees that applicants may approach police stations, Offices for Foreigners, or the Office for Asylum and Refuge (OAR), or that the OAR may initiate the procedure ex officio when it has knowledge, facts, or information indicating that a particular foreigner is stateless. The OAR carries out the procedure, during which the applicant must fully co-operate by providing documentary and oral evidence. The OAR may request reports from other governmental or international bodies. Upon conclusion of the investigative phase, the OAR forwards its reasoned proposal for recognition or non-recognition through the General Directorate for Aliens' and Immigration Issues to the Minister of the Interior. Rejections can be appealed, while a positive resolution results in the granting of the status of stateless person under the terms foreseen in the 1954 Convention. The recognition also includes the right to permanent residence and to seek employment.

In France, a procedure for the recognition of statelessness status exists within the French Office for the Protection of Refugees and Stateless Persons [Office français de protection des réfugiés et apatrides (OFPRA)], although it is not regulated by a legislative or sub-legislative act. "Law $\mathrm{n}^{\circ}$ 52-893 of 25 July 1952 concerning the right of asylum" (formerly named the "Law concerning the creation of an Office for the protection of refugees and stateless persons") gives OFPRA the mandate to provide for the juridical and administrative protection of stateless persons. ${ }^{46}$ French administrative practices and principles extracted from jurisprudence have led to the rules governing France's stateless recognition procedure. An applicant must apply directly to OFPRA, which will take the decision concerning possible statelessness and recognition as a stateless person.

In Italy, an implementing decree to the Nationality Law gives the Ministry of the Interior the authority to recognize the stateless status. ${ }^{47}$ When the matter is uncomplicated and a simple examination of available documentation will suffice to show that the applicant is no longer a national of the particular State in question, the procedure is run by the Ministry of Interior. If the applicant does not have required documentation and the matter involves an examination of foreign legislation, the applicant's case must be addressed to the civil courts, which can also recognize a person to be stateless.

In Belgium, on the other hand, because the matter is not regulated by law, the Tribunals of First Instance have asserted their jurisdiction in the determination of the personal status of an individual. ${ }^{48}$

Other countries, such as Germany, have procedures by which a person can apply for a 1954 Convention Travel Document, thereby requiring relevant authorities to examine the question of whether the person is stateless. The matter may also arise when the applicant requests a residence permit. Yet, possibly because there is no specific procedure for determination of whether statelessness exists, the authorities do not issue a specific decision on the question of whether the individual is stateless. In Austria, the question of statelessness usually arises incidentally to efforts to try and establish the identity of a foreigner. Once procedures have been exhausted, and in cases where no nationality can be established, the person may be considered stateless.

In other countries having no specific recognition procedure for stateless persons, the matter arises in asylum procedures or as a subsidiary question when applications for residence permits or travel documents are made. ${ }^{49}$ More often than not, it seems that if the question arises in the asylum procedure, the matter of determining whether the applicant is in fact stateless only becomes prominent if the person's asylum claim is rejected. In such cases, the question of permission to remain on other grounds may arise. This can include stay on humanitarian grounds due to length of stay in the country, the existence of school-age children who have integrated, or the fact that removal from the country is not possible because there is no country to which to send the person. The latter situation arises frequently in cases of statelessness, even though no specific finding of statelessness has necessarily been undertaken.

While this may result in the State granting leave to remain on humanitarian or non-removability grounds, it does little to identify cases of statelessness generally and, therefore, misses an opportunity to address the broader question of identifying increased flows of stateless persons due to changed circumstances in their countries of origin. Harmonization of approaches in this area and sharing of information on general trends concerning population displacement due to statelessness could serve as a critical 
early-warning mechanism to help both States of origin and receiving States address unfolding root causes of statelessness.

It is unclear why so many EU Member States lack a specific legal framework, including a procedure, by which statelessness can be determined. A possible reason may be that in the majority of these States, stateless persons tend to show up in refugee status procedures and are dealt with in this framework, including the framework for humanitarian or subsidiary protection. Certainly, for stateless persons with claims of persecution, the asylum framework is the appropriate channel in which to present themselves to the authorities. Yet, in instances where no laws or specific procedures exist to implement the 1954 Convention, it appears that States are grappling nonetheless with the issue of stateless individuals on their territories and are finding ad hoc approaches to addressing it. To some extent, stateless persons may be obliged to channel their application through the asylum framework specifically because there is no other procedure available. Moreover, without specific procedures aimed at identifying stateless persons, it remains unclear how many cases are left unnoticed and unidentified within the EU. It is, therefore, impossible to determine the magnitude of the problem of statelessness within EU Member States as there is no consistent way of identifying cases.

\section{B. Elements of Proof}

As concerns providing evidence to support a claim of statelessness, generally the burden is on the applicant to provide documentation from the Embassy or Consular authorities of the "country of origin" - often the country of birth or a country which issued a prior travel document - confirming that the applicant is not a national.

In Italy, when the applicant is able to provide such documentation certifying his or her statelessness, the Ministry of Interior will take a decision on the case. If, however, the matter is more complicated and demands an inquiry into the nationality laws of other States, then a civil court must examine the case. Thus, in the procedure before the Ministry of Interior, the applicant is requested to submit a request enclosing a birth certificate, documentation certifying residence in Italy, and either documentation effectively demonstrating statelessness status or a declaration by the Consulate of the country of origin or residence. If the person does not have all documentation requested, then an application will have to be submitted to the competent ordinary judicial authority with a procedure in "Camera di Consiglio." The applicant will have to prove statelessness with whatever elements of proof are available, including review of relevant nationality laws, witnesses, and declara- tions of third parties. If recognized by the court, a decree recognizing the statelessness of the applicant will be issued and notification of this will be forwarded to the Provincial Police Headquarters (Questura).

In Belgium, the burden of proof in providing sufficient facts to demonstrate statelessness is on the applicant. The courts and tribunals consider one's statelessness sufficiently proven if the person can demonstrate not to have the nationality of countries of substantial links, including the country of birth, country in which a parent or spouse has nationality, and so on. In many cases, however, it is difficult for the applicant to produce sufficient evidence or documentation for the establishment of statelessness status. In Germany, the burden of proof is on the applicant while in France the claimant has to provide evidence of a lack of nationality, either documentary or by other means which would clearly indicate statelessness.

In Austria, statelessness is determined on the basis of available evidence, including relevant documents, and credible statements by the person concerned or others. In cases in which no documents are available, the determining officer may use the statement of the alien, but given that the issue arises in the context of an application for a residence permit or in an asylum procedure, the finding will not lead to a status as stateless. In yet another State, the practice suggests that if the applicant is unable to provide such certificates, the Contracting Party will not make an assessment as to statelessness and will not approach other States for information unless trying to deport the applicant.

Clearly there is room here for developing a more consistent approach to the problem of statelessness and to the implementation of the 1954 Convention within EU Member States. The search for information may require a collaborative approach between various departments and ministries within a government, as well as with other States. For example, the implementing decree in Spain sets out that while carrying out its investigative function, the OAR may request as many reports as it deems appropriate from the central administrative bodies as well as from any other national or international entity, a positive practice which could be furthered in other jurisdictions. ${ }^{50}$ Additionally, while an individual may typically have the burden of proof, the criteria for establishing proof may vary from State to State. There is, therefore, a risk that a person recognized as stateless in one State will not be recognized as between States.

\section{Designated Decision Maker}

Another area which would lend itself to harmonization of approaches is that of a designated decision maker. As the majority of States in the EU have not adopted legislation to 
provide for specific recognition procedures, it also follows that there are often no designated decision makers. In States where the procedure is in place, it has been accorded to bodies which also deal with asylum issues: in France, the Office français de protection des réfugiés et apatrides and, in Spain, the Office for Asylum and Refuge within the Ministry of Interior.

In Germany, the local aliens' authorities make determinations on residence permits and 1954 Convention Travel Documents, while if the issue arises in Austria, it is also local authorities or aliens' police who deal with the matter insofar as it concerns determining the individual's identity.

In Italy it is within the competency of the Ministry of Interior to assess applications for the status of a stateless person, unless the matter is complex, at which point it goes before a civil court. On the other hand, in Belgium the Tribunal of First Instance is competent for recognizing an individual as stateless. The Court of Appeal has held that this decision is not within the jurisdiction of the Minister of Justice, given that there is no legislative act assigning such responsibility. Although a Commissariat Général aux Réfugiés et aux Apatrides exists, its enabling legislation gives it competence to deliver documents stipulated in Article 25 of the 1954 Convention only. ${ }^{51}$

In all other States, with the possible exception of Luxembourg, it is the authorities responsible for foreigners and immigration or asylum who deal with stateless persons; that is, either the Ministry of Interior or the Ministry of Justice, depending on the country. ${ }^{52}$

Given the specialized nature of the determination required under the 1954 Convention, a clearly identified authority (where possible, a single central authority), having expertise in the field of statelessness is an intrinsic aspect of the procedure. ${ }^{53}$ Qualified and specialized personnel who can make an impartial and objective examination of the application should have the responsibility to determine the claim, distinct from any claim for asylum.

A central designated authority would reduce the risk of inconsistent decisions being taken at the local level and would also aid in the collection and dissemination of country-of-origin information for similar caseloads. Moreover, a designated authority would have better opportunity to develop its competence and expertise in statelessness matters. Those officials a stateless person might approach, such as border officials or immigration officers, should have clear instructions on handling such cases and on referrals to the designated authority. Liaison with other States normally does require co-operation with and through the Ministry of Foreign Affairs, and to some extent such co-operation must also be centralized with regard to agencies, such as UNHCR, which have expertise in this area.
Harmonizing approaches both within and between States is, therefore, an essential component of fully implementing the 1954 Convention in EU Member States.

The determination of statelessness requires the collection and analysis of laws, regulations, and practice of other States. Even without a central authority, decision makers will benefit from a collaborative approach that systematizes the use of existing contacts and areas of expertise within the government structure and as between States.

\section{Access to the Procedure and Due Process of Law}

The 1954 Convention does not impose on States an absolute obligation to admit to their territory stateless persons who are not asylum seekers and who have no particular connection with the State. However, an evaluation of nationality status may nonetheless be a precursor to identifying solutions once a person is within a State's jurisdiction. If the individual is indeed stateless, and if there is no possibility of return to the country of former habitual residence or if there is no such country, then admittance to the territory and some type of legal stay may be the only solution. Indefinite detention would contravene human rights principles. In any case, it should be noted that under the 1954 Convention, lack of legal admission is not a bar to determining whether an individual is stateless. Moreover, a finding of statelessness does not dictate the solution to be adopted.

France, Belgium, and Italy do not bar an individual from requesting recognition as a stateless person although not formally admitted to the State's territory. In Spain, where a procedure framework has been set out, the implementing decree specifies a one-month time limit after entering Spain for lodging the application, unless the foreigner has legal stay. If lodged after a month of irregular stay in the country, or only after an expulsion order has been issued, then the claim is presumed to be unfounded. ${ }^{54}$

The Convention is silent as to whether legal stay shall be granted while the request for recognition as a stateless person is being assessed. The practice in States with a dedicated procedure varies. In Spain and Italy, for example, the applicant can receive a temporary residence permit while the claim is being examined, ${ }^{55}$ while in France there is no right to temporary residence and the applicant could be removed before the application has been decided.

Similarly, in Belgium the Aliens' Office does not automatically grant a temporary residence permit to an individual while the Tribunal of First Instance or the Court of Appeal is examining the application. Yet, before the Tribunal decides on the case, the applicant cannot be expelled, thus leaving the applicant in the incongruous situation of illegally staying in Belgium without the possibility of removal. The Tribunals and Courts have on several occasions 
issued an injunction to the authorities to grant a temporary residence permit to applicants in the determination procedure; ${ }^{56}$ nevertheless, in practice only when a judicial decision is taken on an individual case will a permit be issued. The courts have examined the requests in the light of the subjective right to recognition of one's stateless status as well as with reference to Articles 3 and 6 of the European Convention on Human Rights and Fundamental Freedoms. ${ }^{57}$

If an application has been made, or if the authorities are trying to determine whether an individual is stateless, then it may be necessary to provide for temporary stay while the process is underway. In any event, the individual will in most cases remain factually present and may be left in a clandestine situation for a significant period if the procedure is lengthy.

The principle of due process requires that applicants be assured certain guarantees. Such guarantees should include the right to an individual examination of the claim with the participation of the applicant; the right to objective treatment of the case; limitations as to the length of the procedure; access by the claimant to information on the procedure in a language which is understood; access to legal advice; an interpreter; the right to confidentiality and data protection; delivery of a decision with the rationale; and the possibility to challenge the legality of that decision.

Countries in the EU have generally adopted mechanisms to ensure procedural guarantees connected to administrative procedures, including those involving questions related to the stay and status of aliens. In Spain, certain procedural rights are embodied in the implementing decree, including specific rights for minors and the right to an interpreter. General provisions are contained in the aliens' legislation and in the Law on Administrative Procedures. However, Spain's implementing decree sets out that statelessness status may be decided upon written submissions made by the applicant and does not give a right to an individual interview. Given that the applicant will be a key source of information, facts might best be collected through an individual interview with the applicant wherever possible.

In France, although without specific legislation to regulate its statelessness procedure, procedural rights are governed by the administrative law and the principe $d u$ contradictoire from which every person benefits. Applicants submit an application to the OFPRA, after which they are called for an individual interview. ${ }^{58}$

In some countries, there is no right to pro bono legal advice during the administrative procedure but only on appeal, and in certain instances conditioned on being indigent or having a claim that is likely to succeed. However, in Italy, when the recognition procedure is before the courts, the Italian Refugee Council and other Non-Governmental
Organizations may, at times, provide some support. In Spain, the implementing legislation provides that recognized associations for the advice and aid of stateless persons may issue reports to the authorities in support of applications for stateless status.

Certain categories of applicants for stateless status, particularly unaccompanied children, may have special needs requiring distinct procedural provisions. Although few of the EU States have legislation which addresses the specific issue of unaccompanied stateless children, ${ }^{59}$ most of these States have special procedural guarantees for unaccompanied children generally. These include the appointment of a guardian to represent or assist the unaccompanied child during an administrative procedure. Other States are in the process of amending their legislation in order to ensure that a guardian is made available to unaccompanied children, although in at least one EU Member State there is no particular protection for unaccompanied children unless they apply for asylum.

The right to an effective remedy is a key principle of the European Convention for the Protection of Human Rights and Fundamental Freedoms. The right to an appeal or review mechanism is found in most of the Member States, although this can vary depending on the administrative law standards applicable. Regardless of whether the statelessness procedure is specifically defined, or is part of a procedure to acquire a residence permit or a travel document, a right of review is generally included. Nevertheless, in some jurisdictions where no procedure exists and, rather, a discretionary power is used to grant a stay of deportation or temporary or exceptional leave to remain to someone that is or could be stateless, there are no rights of review. Harmonization on this point would help to avoid different results from jurisdiction to jurisdiction.

\section{The Effect of Recognition}

\section{A. Admission and Legal Status}

If a person is found to be stateless, the question of granting lawful admission will become relevant. This arises with regard to admission based on statelessness and the need for the person to acquire a legal status, rather than admission solely on the grounds of non-removability. The 1954 Convention actually provides for several legal categories because it is intended to address a variety of situations which might arise within a State as well as between States. Questions of implementation will arise with regard to: the situation of stateless persons lawfully admitted to the State; the situation of stateless persons lawfully admitted to another State Party and any ensuing implications arising between States Parties; and the situation of stateless persons who have not been granted lawful admission. ${ }^{60}$ 
In short, the 1954 Convention does not require a State, even when it finds a person to be stateless, to grant entry. The reference point for treatment of stateless persons generally is Article 7(1), which stipulates that except where the Convention explicitly contains more favourable treatment, "a Contracting State shall accord to stateless persons the same treatment as is accorded to aliens generally." This is the underlying base and, as is required of aliens generally, adherence to immigration laws is also required of stateless persons. This is reinforced in Article 6, which provides that requirements which a non-stateless person in the same circumstances would have to fulfill for the enjoyment of a right provided for in the Convention, a stateless person is equally expected to fulfill, with the exception of requirements which by their nature a stateless person cannot fulfill. While this article is not addressing the question of entry per se, it indicates that the drafters were holding stateless persons to standards expected of all persons insofar as this is possible. ${ }^{61}$ Again, it should be noted that as there is no well-founded fear of persecution at issue, there is no equivalent in the 1954 Convention to Article 31 of the 1951 Refugee Convention. ${ }^{62}$

This approach is reinforced in the object and purpose of the Convention itself. The goal of the international community in drafting the 1954 and 1961 Statelessness Conventions was principally to ensure, under the 1961 Convention, that statelessness is avoided and the number of cases reduced. In instances where statelessness nonetheless occurred, the objective was to promote the recognition of the person as stateless under the 1954 Convention and access to basic rights and freedoms without discrimination. The acquisition of a legal status at the national level could serve as a platform for normalizing stay in a given country and for potentially acquiring nationality. However, this does not translate into an absolute entitlement to legal stay in any country. It should also be borne in mind that the 1954 Convention assumes the individual concerned does not have a well-founded fear of persecution, as any such cases would necessarily fall under the asylum regime and the 1951 Refugee Convention.

For those who are found to be stateless and are not excluded under Article 1(2), the starting point is Article $7(1)$, which establishes that treatment should be no less favourable than that granted to aliens, which would include basic notions of human rights which are not dependent on legal status in a given country (for example, prohibitions against torture). This is reinforced by Article 2, which provides that every stateless person "has duties to the country in which he finds himself, which require in particular that he conform to its laws and regulations as well as to measures taken for the maintenance of public order." This would include conformity to the immigration laws and regulations of a country. ${ }^{63}$

This does not mean to say that a person should be automatically excluded because of unlawful presence, not least because what constitutes lawful or unlawful stay may be difficult to attribute to the individual him or herself. For example, a person may enter a country with a valid passport and required visa. If the country in which that person holds nationality arbitrarily strips that person of nationality while the individual is abroad, and the person is consequently unable to leave before the expiration of the visa, that person will be "unlawfully" in the country. Yet, the individual should not be held accountable for acts of the State of nationality particularly where they run counter to international legal norms.

In such a case, a State Party to the 1954 Convention can choose to review the case and determine whether the person is stateless, and then has several options. First amongst these might be to determine the appropriateness of trying to negotiate a reinstatement of the individual's nationality, particularly in cases where it has been arbitrarily removed. ${ }^{64}$ The State Party can apply Article 7(1) and may decide against legalizing the stay of the person concerned. In this case, it would be appropriate for the Contracting State to provide the stateless person with a travel document so as to seek entry to another State. The State Party could also admit the person for either temporary or permanent stay.

Within the EU, those States with statelessness determination procedures defined by law foresee the possibility of granting residence. Those without such procedures nevertheless often find that there is no other alternative but to grant a form of stay. Leaving an individual indefinitely in an illegal position is not a viable option and if a removal order cannot be enforced because of the statelessness, there are few alternatives. Even when removal from the territory is feasible, if a State does not have a statelessness determination procedure which incorporates the exclusion clauses outlined in Article 1(2), then they will not necessarily have exhausted the options concerning any potential country of former residence which will readmit the individual or which would meet the requirements outlined in Article $1(2)(i i)$. In this sense as well, ensuring an effective procedure is in place promotes the use of a broader set of options for the State Party.

Particular guarantees would need to be confirmed before return to a State should be pursued. If nationality has been renounced or deprived leaving the person stateless, then automatic reacquisition would be the most appropriate solution. If the person had lawful residence which is still recognized, and has access to social and economic rights equivalent to that of a national or at a minimum equal to 
those outlined in the 1954 Convention, then return may be possible. Certain persons may, nonetheless, have established significant links making return inappropriate on humanitarian grounds (for example, where they have been present for many years in the Contracting State and are highly integrated, or in case of family ties). When the return of a stateless person is included in a readmission agreement, guarantees should be sought such as reacquisition of nationality or permanent residence as appropriate.

A State having recognized an individual to be stateless may decide not to grant residence if another Contracting State has already made the same determination. If the latter State has granted permanent residence, then a right of return should exist. By issuing a Convention Travel Document (CTD), the Contracting State is required to entitle the bearer to re-enter during the period of its validity, unless a provision to the contrary has been recorded in the document. ${ }^{65}$ Thus, while the CTD is valid, the right of return exists. Yet, possibilities could be explored for the readmittance of the stateless person even after expiry of the CTD. Such situations would require negotiations between States in order to ensure a possibility to return and the continuing entitlement to residence in the first State of recognition. This is a clear area where harmonization of approaches between EU Member States would be of assistance.

As earlier noted, the majority of countries in the EU do not anticipate an automatic right to residence based on recognition as a stateless person. Those countries with designated statelessness determination procedures do provide for residence based on recognition as a stateless person. ${ }^{66}$ In the majority of other States, stateless persons tend to receive permission to stay on humanitarian grounds, often granted without a formal finding of statelessness. ${ }^{67}$ This may be done when the stateless person is unable to leave the country for reasons beyond their control. ${ }^{68}$

In those countries having a dedicated procedure, including France, Italy, and Spain, recognition as a stateless person leads to residence. Spanish legislation grants permanent residence to stateless persons, while in Italy, the residence permit is granted for a period of two years. ${ }^{69}$ In France, the aliens' legislation provides that those who obtain the status of stateless persons are granted a one-year carte de séjour temporaire conferring the right to work. The residence will be renewed if the stateless person continues to fulfill the conditions upon which the permit was originally granted..$^{70}$ After three years, the holder and family can receive residence permits for ten years, unless they constitute a threat to public order. ${ }^{71}$

In those countries not having specific procedures for identifying stateless persons, the approach varies. A common thread is that most countries in the EU have a mecha- nism to grant a form of stay, whether on humanitarian grounds or other, with reference to the aliens' and asylum frameworks. In one country, however, while the humanitarian basis exists, it is not often used in practice to grant residence to stateless persons, thus leaving them in a state of legal limbo.

Leave to remain on asylum or humanitarian grounds may be granted for either definite or indefinite periods. In situations where it is of a temporary nature, particularly if renewal is not automatic but left to the discretion of the issuing authority, the recognized stateless person is left in continued uncertainty until able to apply for permanent residence, which can range from three to five years depending on the country. ${ }^{72}$

The European Council recently reached agreement on the "Draft Directive concerning the status of third country nationals who are long-term residents," 73 which sets five years as the period of legal and continuous residence following which Member States shall grant long-term residence status. This Directive will not apply to refugees or those who are authorized to reside in a Member State on the basis of a subsidiary form of protection in accordance with international obligations, national legislation, or the practice of Member States, or to those who have applied for authorization to reside on such basis. Of concern is the fact that in some Member States, the status received by stateless persons is considered a subsidiary form of protection, and would thus be outside the Directive, while in others it is not considered a subsidiary form of protection. Here is an area where harmonization of approaches to residence should relate to harmonization of approaches to the determination of statelessness, as the current situation will lead to varying results depending on the State in which a person is recognized.

Other States make the issuance of a residence permit conditional on the stateless person being unable to leave due to reasons beyond the individual's control. Voluntary renunciation of nationality or refusal to seek confirmation of a nationality would, therefore, exclude issuance of the permit. ${ }^{74}$ Even where the individual is unable to leave, there may be a time period before the residence permit can be issued. ${ }^{75}$ The decision in this regard may be left to the discretion of local authorities, leading to a variety of approaches depending on the region.

In some EU Member States, stateless persons have sought to regulate their stay through periodic regularization procedures concerning migrants. ${ }^{76}$

The grant of residence is of particular importance given that it is essentially through this that the stateless person will be able to access the full rights and benefits provided for in the 1954 Convention. In the European Union, rights 
and benefits available to stateless persons are often attached to the type of residence permit that is granted. Those granted leave to remain on humanitarian grounds may receive rights equivalent to those of recognized refugees, depending on the legislative framework or State practice. In other States, economic and social rights may not be granted to persons permitted to stay on humanitarian grounds or temporary leave to remain. Family reunification rights may vary depending on the type of stay granted.

\section{B. Access to Rights and Benefits: Overview of Convention Provisions}

Many of the Convention provisions concern social and economic rights covered, within the EU, by national laws and relating also to European Union Directives, jurisprudence of the European Court of Justice, and other sources. Once a foreigner has residence in an EU Member State, social and economic rights are similar to those for nationals of the Member State concerned, although distinctions may be found. Certain rights may also be linked to the grant of permanent residence. It must be noted, however, that as there is no common EU approach to the determination of statelessness under Article 1 of the 1954 Convention, there is a consequent lack of harmonization of the remaining provisions of the 1954 Convention specifically with regard to recognized stateless persons.

For purposes of this study, a key objective was to analyze the tools and mechanisms in place to address issues of statelessness. Without the tool or mechanism in place to identify and recognize stateless persons specifically with regard to their statelessness, the remaining provisions of the Convention will be available to stateless persons only insofar as they are available to populations generally. The lack of such a framework is, in fact, a key finding of the study and the basis on which recommendations have been elaborated.

Nonetheless, an overview of the provisions of the Convention will shed light on which measures are needed to ensure both implementation of the instrument and harmonization of approaches as between States. This assessment has been made to facilitate development of such frameworks.

In instances where lawful stay is granted, a Contracting State will need to ensure that the recognized stateless person has access to rights, at a minimum, on par with those outlined in the Convention. ${ }^{77}$ There are also obligations for the individual. Article 2 of the Convention stipulates that a stateless person has "duties to the country in which he finds himself, which require in particular that he conform to its laws and regulations as well as to measures taken for the maintenance of public order." As such, the Convention is stipulating that a stateless person will, in addition to any rights provided by the State, have duties and obligations toward the State based on the legal framework. Moreover, further to Article 6, certain entitlements specify that a stateless person must fulfill any requirements which other persons in similar circumstances, including aliens generally, would be required to fulfill unless they are requirements which a stateless person by definition cannot fulfill.

There are certain fundamental human rights that apply to all persons regardless of their status or type of stay in a particular jurisdiction. These rights must be respected and protected by the State in whose territory an individual is present. The principle of non-discrimination is one of these rights and guides the implementation of the provisions of the 1954 Convention. This principle has developed extensively since the drafting of the 1954 Convention, and thus its application would extend beyond the factors of race, religion, and country of origin specifically enumerated in Article 3.

Notably, the International Covenant on Civil and Political Rights (ICCPR $)^{78}$ provides in Article 26 that all persons are equal before the law and are entitled without any discrimination to equal protection of the law. The law of the States Parties shall prohibit any discrimination and guarantee to all persons equal and effective protection against discrimination on any ground such as race, colour, sex, language, religion, political or other opinion, national or social origin, property, birth or other status. The ICCPR provides for protection against arbitrary detention and torture, and the right to recognition everywhere as a person before the law.

Other international and regional human rights instruments also reinforce the principle of non-discrimination, which forms part of the legal system of all EU Member States. In Europe, the human rights of stateless persons are also protected by the ECHR. ${ }^{79}$ In this context, standards of treatment of stateless persons or those seeking this status should, inter alia, be consistent with provisions relating to the prohibition of inhumane or degrading treatment and the principle of non-discrimination.

Article 4 of the 1954 Convention provides for the right to freedom of religion. ${ }^{80}$ This right is widely respected by the constitutions and legal systems of the Member States of the EU. The 1954 Convention requires the Contracting Party to accord stateless persons rights as favourable as those accorded to nationals with respect to freedom to practice their religion and freedom regarding the religious education of their children.

The fact is that once a person has acquired lawful status in one of the EU Member States, most of the provisions concerning economic and social rights will fall into place 
although, as noted earlier, this will depend to some extent on the type of stay granted. Article 7(1) of the Convention outlines the general rule that the Contracting States shall accord to stateless persons the same treatment as is accorded to "aliens generally" unless the Convention contains more favourable provisions. According to Robinson:

The reason is that the term 'aliens generally' contains in itself all restrictions which could result from either of the aforementioned requirements. If an 'alien generally' is accorded certain rights without the requirement of residence (permanent or temporary) in the country concerned, a stateless person will enjoy these same rights; if, to be accorded a right, the 'alien generally' must fulfil certain requirements which are contained in the expression 'in the same circumstances', a stateless person not fulfilling them cannot enjoy them under the treatment accorded by paragraph 1 because he is not supposed to be treated more favourably than the hypothetical 'alien generally'. The same must be true of 'illegal' stateless persons: if an alien illegally in a country enjoys certain rights, the same rights must be accorded to a stateless person. ${ }^{81}$

Thus, the general framework outlined by Article 7 is that stateless persons should have access to rights and benefits at a minimum equal to those guaranteed to aliens generally.

Under Article 7(2), a recognized stateless person will be exempt from legislative reciprocity after residing three years in the territory of a Contracting State. States often accord certain rights to aliens based on how their own nationals are treated in the State in which the alien is a national, hence the notion of reciprocity. A stateless person, having no country of nationality, cannot benefit from broader rights granted to certain aliens unless an exemption to this rule is made. This provision was not meant to apply to rights conferred on particular nationals by way of treaties between States; therefore the drafters included the word "legislative." Article 7(3) requires States not to impair existing rights already accorded on the basis of reciprocity only, while Article 7(4) requires States to consider favourably the possibility of granting even broader rights.

Article 8 provides that if the Contracting State invokes exceptional measures against the person, property, or interests of nationals or former nationals of a foreign State, such measures should not be applied to a stateless person solely because of prior possession of the nationality concerned. Article 9 outlines that nothing in the Convention shall prevent a Contracting State from taking provisionally measures which are considered necessary in time of war, for example, in the interests of national security. Article 10 addresses cases of displacement of stateless persons in the context of the Second World War, while Article 11 encour- ages Contracting States to give sympathetic consideration to the plight of stateless seamen serving as crew members on ships flying the flag of the State concerned. Articles 7 to 11, therefore, provide a general outline to Contracting States of how to approach specific issues which might arise in relation to stateless persons under their jurisdiction.

Article 12 addresses the personal status of stateless persons, that is, the legal system which is relevant for purposes of their civil status and previously acquired rights. This is particularly important for stateless persons, as matters concerning personal status are often determined by the law of the country of nationality. Uncertainty in matters of personal status severely affects not only the stateless person, but also others who may wish to enter into a legal relationship with the individual, including marriage. Article 12(1) provides that the law of the country of domicile will take precedence and, absent a country of domicile, the country of residence. Article 12(2) requires that previously acquired rights (such as marriage) shall be respected by the Contracting State, provided that the right in question is one which would be recognized by the Contracting State had the individual not become stateless. An example would be the prohibition against polygamous marriages in Europe.

Article 13, concerning movable and immovable property, provides that stateless persons should receive treatment as favourable as possible and no less favourable than that accorded to aliens generally in the same circumstances. National legislation pertaining to aliens does not normally place conditions on the acquisition of movable property. However, national legislation might regulate acquisition or leasing by foreigners of immovable property. Since the minimum standard against which the right of the stateless person should be measured is that which is applied to aliens generally, the implementation of this article should not be at issue in the EU Member States. Efforts may, however, be needed to harmonize a more consistent approach to the issue at the Community level with particular regard to the situation of stateless persons.

A need to harmonize approaches arises with regard to Article 14 concerning artistic rights and industrial property, in particular because the rights accorded to a recognized stateless person with habitual residence in a Contracting State must, under this Article, be equivalent to those accorded to nationals. While in the territory of any other Contracting State, the recognized stateless person shall be accorded the same protection as is accorded in that territory to nationals of the country in which the person has habitual residence.

This means that a stateless person recognized and habitually resident in Spain, for example, would be entitled to treatment equal to that extended to Spanish nationals while 
in Spain, and equal to that of Spanish nationals while in the territory of France, Sweden, or any other Contracting State. Certainly the regulation of artistic rights, industrial property, and intellectual property represents a legal sphere of its own with highly sophisticated systems in place. At a very general level, Article 27(2) of the Universal Declaration of Human Rights provides: "Everyone has the right to the protection of the moral and material interests resulting from any scientific, literary, or artistic production of which he is the author." 82 In implementing the 1954 Convention and particularly with a view to harmonization of approaches, EU Member States may need to pay particular regard to this provision.

Under Article 15 concerning the right of association as regards non-political and non-profit-making associations and trade unions, a Contracting State shall accord to stateless persons lawfully staying in their territory treatment as favourable as possible and, at a minimum, the treatment granted to other aliens. Human rights instruments accord to all persons the right of association. ${ }^{83}$ The right of association is generally provided for in the Constitutions of EU Member States.

Another fundamental principle found in the legal systems of the Member States of the EU is that any person within a State's jurisdiction will have unimpeded access to courts of law in order to enforce their legal rights. ${ }^{84}$ Constitutions of EU Member States generally protect this right, in line with Article 16(1) providing that a stateless person shall have free access to the Courts of Law on the territory of all Contracting States. As regards Articles 16(2) and (3) concerning access to the Courts and including legal assistance, a stateless person should be treated on par with nationals in the place of habitual residence when in the State of residence as well as when in another Contracting State. As noted above, this will have particular implications within and between EU Member States and will require harmonization of approaches to ensure the implementation of the Convention.

Article 17 concerning wage-earning employment provides that stateless persons lawfully staying in a Contracting State's territory be granted treatment as favourable as possible and, in any event, not less favourable than that accorded to aliens generally in the same circumstances. The phrase "wage-earning employment" is meant to include any paid employment and should be understood in its widest sense. ${ }^{85}$

State Parties are also requested to give sympathetic consideration to assimilating the rights of stateless persons to those of nationals with regard to wage-earning employment.

Article 18, concerning the right to engage in self-employment, stipulates that a Contracting State shall accord to a stateless person lawfully in their territory treatment as favourable as possible and, in any event, not less favourable than that accorded to aliens generally in the same circumstances. Activities possibly falling into the category of selfemployment include agriculture, handicrafts, and commerce and establishment of commercial and industrial companies. In the European Union, the right to work is normally guaranteed to aliens holding some form of legal residence. In France, even though only temporary residence is given to a stateless person upon recognition, the right to work is still accorded.

Under Article 19, a Contracting State shall accord to stateless persons lawfully staying in their territory who hold diplomas recognized by the competent authorities of the State treatment as favourable as possible and not less favourable than that accorded to aliens generally in the same circumstances. National authorities determine liberal professions, although these typically could include medicine, law, and engineering. Such mechanisms are generally provided for in national legislation of EU Member States as applicable to foreigners, and are regulated within the EU. Section 37(1) of Italy's LD 286/1998, for example, provides that lawfully resident foreigners who hold qualifications legally recognized in Italy which entitle them to exercise a profession are entitled to register with the professional Rolls or Councils, an exception to the general provisions requiring Italian nationality.

While approaches are largely harmonized within the EU as concerns recognition of diplomas and practicing professions for nationals of EU Member States, no such system exists with regard to stateless persons specifically who have been recognized by a Member State, meaning such persons fall into the system in place for aliens overall. In instances where the Convention suggests treatment "as favourable as possible" because the person is stateless, there will often be no way of actually identifying the individual for more favourable treatment, and no legal reference point for extending such treatment if the stateless person is identified from amidst aliens generally. This area would require further development for full implementation of Article 19.

Article 20 provides that where a rationing system exists which applies to the population at large and regulates the general distribution of products in short supply, stateless persons shall be accorded the same treatment as nationals. Article 20 is not applicable to the allocation to specific groups, such as indigent persons, large families, or those on social welfare, of products which are in supply and provided at more favourable conditions or prices. Article 7(1) would apply in such circumstances, which requires the Contracting State to accord to stateless persons the same treatment as accorded to aliens generally. 
Article 21 provides that in countries where housing is regulated by law or is subject to the control of the public authorities, stateless persons should at a minimum be accorded the same treatment as aliens generally in the same circumstances, although more favourable treatment is recommended. This article deals with rent control and assignment of premises and must be observed by all public authorities. ${ }^{86}$ Laws applicable to foreigners generally regulate this issue within individual EU Member States. ${ }^{87}$

Concerning Article 22 and the right to primary education, this is a recognized human right ${ }^{88}$ and one that is integrated into the legal systems of all Member States of the EU. The 1954 Convention requires that State Parties shall treat stateless persons the same as nationals with respect to elementary education. Beyond the level of primary education, the Convention requires that stateless persons are treated as favourably as possible, and not less favourably than aliens generally in the same circumstances. Legal stay of the stateless person is not at issue with regard to primary education, while if aliens generally are required to be legally resident in order to access secondary or other education, then the same requirement could be applied as a minimum standard to stateless persons. In principle, all EU Member States implement the standards required in the Convention on the Rights of the Child and have made secondary education compulsory for all children regardless of the reasons for their stay. ${ }^{89}$

Article 23 is concerned with public relief. Although the meaning of "public relief" is to be defined by national legislation, it should encompass notions of social and medical assistance, including hospitalization, emergency treatment, and social security benefits. The Contracting Party is required to accord the same treatment to stateless persons lawfully staying on their territory as is accorded to their nationals with respect to public relief and assistance.

Germany has made a reservation to this Article, and only stateless refugees will receive the same treatment as nationals. For other stateless persons, public relief is provided to the extent provided for in national legislation concerning aliens. According to German legislation, however, there are only slight differences between the extent of public relief provided to nationals and refugees as compared to aliens. Stateless persons do obtain a number of social rights and may benefit from social aid and medical services. The amount of social aid may be reduced or allocated in kind, however, and after three years social aid will be equivalent to that received by nationals. Certain specific provisions are reserved for nationals, such as allowances for children and certain grants for study purposes. Once the stateless person has obtained permanent residence, they will receive public relief rights equivalent to that of nationals. ${ }^{90}$
In Italy,

Foreigners holding a permanent residence card or residence permit with a duration of not less than one year, together with minors entered on their permanent residence card or residence permit, shall be treated on a par with Italian nationals for the purpose of benefiting from social welfare services, such as financial assistance, including that provided for persons suffering from Hansen's disease or tuberculosis, the deaf and mute, blind and disabled civilians and the destitute. ${ }^{91}$

Under Article 24, Contracting States are required to accord to stateless persons lawfully staying in their territories treatment equal to that of nationals in the field of labour rights and social security. This includes all rights associated with labour and employment, such as remuneration, conditions of work, employment benefits, social security schemes, pension schemes, disability and unemployment rights, as well as rights of beneficiaries residing outside the Contracting State to collect on compensation in event of the death of the stateless person. According to Weis, "The principle of equality of treatment between nationals and aliens as regards labour law can be regarded as universally adopted. The same principle as regards social security is becoming more and more widely spread." 92

Again, the legal framework concerning labour laws and social security is highly advanced within the European Union Member States. Nonetheless, special regard should be paid to Article 24(3), which provides that Contracting States shall extend to stateless persons the benefits of agreements concluded between them, or which may be concluded between them in the future, concerning the maintenance of acquired rights and rights in the process of acquisition in regard to social security, subject only to the conditions which apply to nationals of the States signatory to the agreements in question. In order to implement this provision, it would be necessary that all Contracting States within the EU are able to identify stateless persons and have a mechanism in place to identify stateless persons recognized by other Member States, so as to be able to extend to them the benefits of such agreements.

Article 25 provides that administrative assistance be rendered by the Contracting State in which the stateless person has residence in cases where the individual would normally require the assistance of authorities of a foreign country if recourse cannot be made to authorities abroad. Stateless persons may not in all circumstances be impeded from approaching their countries of origin or former habitual residence; however, the authorities of another country may require that the request pass through official channels, and the country of the stateless person's residence should have a designated authority for these purposes. In certain situ- 
ations, it may be unreasonable to expect that a stateless person can receive administrative assistance from the authorities of their country of former nationality or residence, at which point the administrative services of the country of residence will be critical for providing documents or certifications which would normally be delivered by national authorities.

In terms of administrative assistance, Spain, France, and Belgium have, for example, designated particular bodies responsible for providing the administrative assistance envisaged in Article 25 of the Convention. ${ }^{93}$

Article 26 provides that stateless persons lawfully in the State's territory have the right to choose their place of residence and to move freely within the territory, subject to any regulations applicable to aliens generally in the same circumstances. Human rights principles generally are also relevant to freedom of movement and choice of residence, including Article 13 of the UDHR, Article 12(1) of the ICCPR and Article 2 of Protocol No. 4 of the ECHR.

The entitlement to an identity card under Article 27 is a key aspect of the 1954 Convention. Under Article 27, any recognized stateless person who is physically present in the territory of the Contracting State should receive identity papers if they do not possess a valid travel document. This is a mandatory requirement; however, not all Member States of the EU are implementing this provision and the practice varies greatly. Certainly if there is no procedure in place specifically designed to identify cases of statelessness, there will be instances in which stateless persons remain undocumented.

One State has made a reservation to this Article. ${ }^{94}$ In Belgium, recognized stateless persons receive an attestation certifying that they have been granted such status. In others States, such as Spain, an identity document is given entitling the bearer to permanent residence, while in France, the residence authorization (carte de séjour) acts as the identity card.

If a residence authorization is granted, then most legal systems in EU Member States provide for the issuance of aliens' identification to those with lawful residence. In Ireland, for example, persons who are granted temporary leave to remain receive an alien identification card, known as a green card, which is distinguished according to the status of the bearer..$^{95}$ Overall, this is an area which would greatly benefit from efforts to harmonize approaches, both to ensure that stateless persons have some evidence of their identity regardless of residence or lawful stay, and to ensure that as between EU Member States, documents issued under Article 27 will be recognized.

Article 28 of the 1954 Convention requires Contracting States to issue travel documents to recognized stateless persons lawfully residing on the territory of the State. This document, according to paragraph 5 of the Schedule, should have a validity of not less than three months and not more than two years. Issuance of a Convention Travel Document (CTD) obliges the Contracting State to readmit the stateless person during the validity of the document. ${ }^{96}$

In the EU Member States, the practice varies as to whether a recognized stateless person receives a 1954 CTD or an alien's passport. In certain States, the aliens' legislation provides for the issuance of a 1954 Convention or alien's travel document to stateless persons. ${ }^{97}$ Other States directly implement Article 28 of the 1954 Convention, with the relevant authority issuing a CTD. ${ }^{98}$

In Germany, for example, CTDs are regularly issued in accordance with Article 28 of the Convention. Section 14(2) Nr.2 of the Decree implementing the Aliens' Act provides for their acceptance. ${ }^{99}$ Several German court decisions have clarified that the term "lawfully staying" requires a residence permit. A toleration permit is not sufficient. ${ }^{100}$

Other States in the European Union generally issue travel documents to foreigners who may be stateless and who have lawful residence on their territories. Thus, in some cases, it appears that an alien's passport is given when there is no exact procedure to recognize statelessness but the individual has been granted residence on humanitarian grounds. ${ }^{101}$

As stated above, the Convention sets out guidelines for the validity of travel documents which are not less than three months and not more than two years. The validity of travel documents could be set for a longer period, and this is done in certain EU states. ${ }^{102}$ Article 5 of the Convention provides for rights beyond those outlined, and as the Convention aims to grant stateless persons as many rights as possible, a Contracting State is free to issue a travel document with a validity of more than two years. Notably, however, there is no harmonization amongst EU Member States on this point, and little information concerning the recognition of the various types of travel documents which might be issued to stateless persons by Member States.

The second part of Article 28 invites the Contracting States to issue travel documents to stateless persons who are present in their territory, even if without lawful residence. In particular, States are asked to give "sympathetic consideration" to issuing CTDs to stateless persons who are in their territory and who are unable to obtain a travel document from their country of lawful residence. Given that many stateless persons may not have a country of lawful residence, this provision is of particular importance, as a Contracting State can grant the individual a travel document which will facilitate both identification of the person 
and the possibility of seeking entry to an appropriate State. The CTD is, therefore, a precursor to onward movement in certain instances.

According to paragraph 15 of the Schedule, the issuance of the CTD does not determine or affect the status of the holder, particularly as regards nationality. Moreover, as per paragraph 16, the CTD does not in any way entitle the holder to the diplomatic or consular protection of the country of issue, and does not ipso facto confer on these authorities the right of protection in this regard.

Under Article 29(1), stateless persons should not be subject to duties, charges, or taxes of any kind that are other or higher than those imposed on nationals of the Contracting State. Nonetheless, Article 29(2) allows the Contracting State to apply to stateless persons the same laws and regulations concerning charges with regard to issuance to aliens of administrative documents including identity papers.

Article 30(1) outlines an obligation for Contracting States to permit a stateless person to transfer assets brought to the territory to another country where the individual has been admitted for resettlement. In this context, resettlement should be understood as immigration or entry to a territory for permanent stay. The transfer should take place in conformity with laws and regulations. Such laws and regulations should not impede the actual transfer, but rather regulate how it takes place. ${ }^{103}$

Article 30(2) requests that the Contracting State give "sympathetic consideration" to the transfer of assets in any location, including another country. The phrase "sympathetic consideration" connotes a discretionary election, but with an obligation to address such requests and not to refuse them without good reason. ${ }^{104}$

Article 31 concerns protection from expulsion of a stateless person lawfully in the territory of a Contracting State unless there are national security or public order grounds and the decision has been reached in accordance with due process of law. "Lawfully in the territory" includes persons who may be present temporarily without the intention of permanent stay. ${ }^{105}$ Due process of law requires that procedural guarantees be in place to permit the stateless person to answer to and submit evidence concerning any accusation, to be represented by legal counsel, and to be granted the right of appeal. The term "public order" should not permit the expulsion of stateless persons on social grounds, such as indigence, illness, or disability. ${ }^{106}$ If expulsion does take place, according to Article 31(3), the Contracting Party should not act immediately after a final decision has been reached, but must allow sufficient time for the stateless person to seek legal admission to another country.

Even if not lawfully in the territory, the protection from non-refoulement is relevant under customary international law. The Final Act of the 1954 Convention stipulates that the drafters did not find it necessary to include a direct reference to the principle of non-refoulement, as they believed the principle is generally accepted. The principle of non-refoulement is relevant to human rights instruments such as the Convention against Torture and the European Convention for the Protection of Human Rights and Fundamental Freedoms. The principle of non-refoulement is incorporated into the legislation of all EU Member States.

Harmonization of Article 31 in EU Member States will, as is the case with other provisions, depend on the approach adopted, if any, to stateless persons generally. Spain, for example, has elaborated in its implementing decree that expulsion of a recognized stateless person must be under the terms foreseen in Article 31 of the 1954 Convention and in accordance with procedures established by the general aliens' legislation. Italy has incorporated the Convention into Italian Law; thus its provisions are directly applicable. ${ }^{107}$ States, in general, take the view that expulsion of aliens will take place if a threat to national security or public order has been established, provided there is no risk of refoulement. In some countries, only those aliens who have been granted permanent residence are protected against expulsion. Thus, in States where temporary stay is granted but not automatically renewed, a stateless person could be in jeopardy of expulsion if the temporary stay is not prolonged.

Article 32 concerns the facilitation, as far as is possible, of the assimilation and naturalization of stateless persons. ${ }^{108}$ Facilitated access to nationality for recognized stateless persons will be determined by each State and is subject to the relevant laws of the State concerned, including residence. Such facilitation could include expediting of naturalization proceedings and a reduction of fees. EU Member States have taken different approaches in this regard, in some cases reducing the number of years of required residence for stateless persons as compared to other foreigners. ${ }^{109}$ Some States reduce or waive naturalization fees for stateless persons. In Ireland, the designated Minister has the discretion to waive normal naturalization conditions in the case of stateless persons. ${ }^{110}$

The Convention also requests States to facilitate as far as possible the "assimilation" of stateless persons. This term refers to the integration of stateless persons into the economic, social, and cultural life of the country. ${ }^{111}$ Member States of the European Union generally provide for integration programs for legally resident foreigners. ${ }^{112}$

\section{Family Reunification}

The right to family reunification is not specifically covered by the 1954 Convention. Nevertheless, the right to family 
unity is a principle that is enshrined in the ECHR and other human rights instruments. In the context of the European Union, the right to family reunification of foreigners is regulated by the aliens' legislation, including in regulations concerning specific groups such as refugees. Under the aliens' legislation, the right to family reunification is most often linked to the type of stay, typically permanent residence, unless the person has been granted refugee status. For aliens in general, conditions are very often placed on the applicant, such as a minimum period of stay, sufficient living space, employment, and the financial means to sustain family members.

With regard to stateless persons, family reunification tends to follow this pattern. In Spain, for example, the specific legislation governing the procedure and the rights to which a stateless person is entitled grants the right of family reunification with those family members stipulated in the Aliens' Law. It would appear that stateless persons in Spain are exempt from other preconditions applied to resident foreigners. ${ }^{113}$ In France, the entitlement of a carte de séjour qualifies a recognized stateless person to family reunification under the same conditions as other foreigners, including sufficient space and regular employment. In Italy, recognized stateless persons are treated as other legally resident foreigners. Family reunification is permitted for foreigners holding a permanent residence card or residence permit with duration of not less than one year, issued for employment, self-employment, asylum, and educational or religious reasons. Foreigners applying for family reunification must demonstrate the availability of sufficient accommodation and income. ${ }^{114}$

In Germany, if the stateless person has legal residence he or she may apply for family reunification if not receiving social welfare and sufficient living space is available. Family reunification for those with temporary residence is up to the discretion of the aliens' authorities and will not be granted if the family can be reunited elsewhere, in particular in cases where reunification can take place in a country where the spouse has legal residence. For those with permanent residence, there is an entitlement to family reunification provided the housing and employment conditions are met. In Greece, aliens must legally reside in the country for two years before being permitted to request family reunification. In order to qualify, the applicant must have income to support family members, suitable shelter, and health care insurance.

When leave to remain on humanitarian grounds is granted, rights are normally commensurate with those of refugees, including that of family reunification. In Ireland, where temporary leave to remain can be granted to a stateless person, their situation is largely assimilated to that of refugees (for example, with regard to family reunification entitlements, right to work, social welfare, and so on). In the United Kingdom, the nature of the right to family reunification will depend on whether the person is granted refugee status, humanitarian status, or a discretionary right to remain.

Article 33 requests Contracting States to communicate to the Secretary-General of the United Nations the laws and regulation which they may adopt to ensure the application of the Convention. It would appear that no State Party from the EU Member States has undertaken this step, although notably it would be useful information for furthering the full implementation of the instrument and for sharing best practices within the UN system. Article 34 provides that any dispute between Contracting States which cannot be settled by other means shall be referred to the International Court of Justice. To date there has been no such referral. If States can co-operate in recognizing and harmonizing procedures adopted under this instrument the potential for any need to resort to the International Court of Justice will be greatly reduced.

Contracting Parties to the 1954 Convention should in principle accept the recognition of statelessness made by another Contracting Party. Nonetheless, paragraph 9 of the Schedule indicates that even in cases of individuals who have been recognized as stateless by another State and who are in transit to the territory of final destination, visas for transit can be refused by a State party "on grounds which would justify refusal of a visa to any alien." 115

\section{Conclusion}

Awareness of the problem of statelessness has become more global. While in some instances statelessness and refugee problems overlap, in others statelessness is unrelated to refugee situations and requires a qualitatively different response and expertise. An international legal framework tailored to the problem of statelessness is available in the context of the 1954 Convention relating to the Status of Stateless Persons and the 1961 Convention on the Reduction of Statelessness. These instruments provide the essential elements needed to identify cases of statelessness and to promote solutions.

One of the primary aims in detaching the Protocol relating to the Status of Stateless Persons from the 1951 Refugee Convention, and making it the independent 1954 Convention, was to ensure that statelessness in all its aspects was dealt with in its own right as a problem requiring unique and independent solutions. The 1954 and 1961 Conventions were intended to set in motion the consistent and methodical identification of problems of statelessness and to provide the tools for the eventual elimination of cases of 
statelessness. Ironically, a decrease in the level of attention given to the problem of statelessness actually followed the drafting of these instruments, with periodic reactions in relation to severe and sweeping changes such as the dissolution of States in the last decade. The operational activities requested of UNHCR by the UN General Assembly in 1995 represent both recognition by the international community that the problem of statelessness is not a periodic one and an effort to ensure these instruments, and the solutions they provide, are increasingly promoted and effectively used in addressing statelessness.

The importance of an international framework for the protection of stateless persons and, therefore, of the Statelessness Conventions is clear: they define statelessness, they provide mechanisms for identifying statelessness, they outline appropriate solutions, and they advocate specific national approaches only insofar as is necessary to achieve the reduction of statelessness and to provide a legal status for stateless persons. The 1954 Convention relating to the Status of Stateless Persons is an important tool for States in addressing the issue of statelessness. In practice, and so as to ensure full implementation of this instrument, States need to adopt mechanisms for identifying statelessness and for ensuring stateless persons are provided a legal status in an appropriate country.

Within the European Union, there is generally a common understanding of the legal definition of statelessness, although the approaches adopted to identify and to address individual cases vary from one country to the next. This study has broadly identified mechanisms States have in place to implement the 1954 Convention. Areas where there may be gaps in full implementation of the Convention have been highlighted, with specific mention made of those areas recommended for harmonization of approaches between EU Member States. UNHCR supports the efforts underway to identify any gaps in this regard, and will continue to strengthen co-operation with States and the European Commission toward full and effective implementation of the 1954 Convention relating to the Status of Stateless Persons.

\section{Acknowledgements}

This paper has been prepared by Carol Batchelor, Senior Legal Officer Statelessness, with research and drafting assistance from Brenda Goddard, Legal Officer. The project was funded with support from the European Commission. The document reflects the views of the author only, and the Commission cannot be held responsible for any use which may be made of the information contained therein.

\section{Notes}

1. The word "nationality" is used throughout this paper as a synonym for the term "citizenship." "Nationality" refers to a legal bond between a person and a State.

2. See Revista de Documentaciòn del Ministerio del Interior, Scope and Content of the International Protection, Madrid, 8-9 January 2002, Ministerio del Interior, N. Especial - Diciembre 2002.

3. Convention relating to the Status of Stateless Persons, 1954, 360 U.N.T.S., No. 5158, 117. EU Member States which are party to the 1954 Convention include the United Kingdom, Germany, Spain, France, Belgium, the Netherlands, Luxembourg, Italy, Greece, Ireland, Sweden, Finland, and Denmark. Austria and Portugal are not States Parties to the 1954 Convention.

4. This paper has been prepared by C. Batchelor, Senior Legal Officer Statelessness, Department of International Protection, with temporary research and drafting assistance from B. Goddard, Legal Officer.

5. A Study of Statelessness (New York: United Nations, August 1949) E/1112; E1112/Add.1.

6. N. Robinson, Convention relating to the Status of Stateless Persons: Its History and Interpretation (Institute of Jewish Affairs, 1955; reprinted by the Division of International Protection of the United Nations High Commissioner for Refugees, 1997) [Robinson Commentary], 1-2.

7. Convention relating to the Status of Refugees, 28 July 1951, 189 U.N.T.S. 2545, 137.

8. Ibid.; see also Robinson Commentary, supra note 6.

9. See C. Batchelor, "Stateless Persons: Some Gaps in International Protection" (1995) 7:2 IJRL 232, for an analysis of how the 1954 and 1961 Statelessness Conventions were adopted and following implications for approaching the problem of statelessness at the international level.

10. " $[\mathrm{I}] \mathrm{f}$ one and the same person qualifies as a 'refugee' (under the terms of the Refugee Convention) and as a 'stateless person' (in accordance with [the 1954] Convention) the state must apply ... the more favourable provisions of the Refugee Convention." (Robinson Commentary, supra note 6 at 8).

11. Information and Accession Package: The 1954 Convention relating to the Status of Stateless Persons and the 1961 Convention on the Reduction of Statelessness (UNHCR, Division of International Protection, January 1999).

12. Universal Declaration of Human Rights, UNGA Res. 217 A(111) (10 December 1948).

13. Convention on the Reduction of Statelessness, 1961, 360 U.N.T.S. 5158, at 117, and 989 U.N.T.S. 14458 at 175.

14. Toward this end, it is noteworthy that only eight of the fifteen EU Member States are parties to the 1961 Convention on the Reduction of Statelessness. The 1997 European Convention on Nationality (Eur. T.S. 1977 No. 166) is also relevant for some States in Europe, and the instrument contains provisions designed to promote the avoidance and reduction of statelessness. Only five of the current fifteen EU Member States are party to this instrument. 
15. UNHCR has recently conducted a global survey of States on steps they have taken to avoid and reduce statelessness and to provide protection to stateless persons. See the Preliminary Report concerning the Questionnaire on Statelessness Pursuant to the Agenda for Protection (UNHCR, Department of International Protection, September 2003).

16. Executive Committee of the High Commissioner's Programme [ExCom], Conclusion No.78 (XLVI), 'Conclusion on the Prevention and Reduction of Statelessness and the Protection of Stateless Persons', 1995, endorsed by UNGA Res. 50/152 (9 February 1996). See also ExCom Conclusion No. 90 (LII) of 5 October 2001, which encouraged states "to cooperate with UNHCR in identifying measures to reduce statelessness and in devising appropriate solutions for stateless persons who are refugees, as well as for stateless persons who are not."

17. UNGA Res. 3274 (XXIX) (10 December 1974) See also UN Doc. A/CONF.9/15, 1961.

18. UNGA Res. 31/36 (30 November 1976).

19. Ibid.; see also ExCom Conclusion No. 78, supra note 16.

20. Ibid.; also, Information and Accession Package, supra note 11 at 5.

21. Article 1 of the 1954 Convention defines a stateless person as "a person who is not considered as a national by any State under the operation of its law."

22. UNHCR can provide technical and advisory services to States in review of the status of persons. In some States, UNHCR has observer status in the statelessness status determination procedure.

23. The 1961 Convention does not contain a definition of a stateless person and it is generally recognized that the 1954 Convention definition is applicable. The explanatory notes to the 1997 European Convention on Nationality state that: "As regards the definition of statelessness, reference is made to Article 1 of the 1954 Convention relating to the Status of Stateless Persons." See Council of Europe, Eur. T.S. 1977 No. 166.

24. In 1948, the Economic and Social Council of the United Nations requested a study "of the existing situation with regard to the protection of stateless persons." The study was to make recommendations "...on the interim measures which might be taken by the United Nations [and] as to the desirability of concluding a further convention on this subject." See P. Weis, "The Convention relating to the Status of Stateless Persons" (April 1961) 10 ICLQ 255-64. In the report prepared by the Secretary General of the United Nations, it was proposed, inter alia, that an international convention concerning the legal status of stateless persons, whether de jure or de facto, be concluded (ibid. at 256). During the 1954 Conference of Plenipotentiaries, however, it was decided that the Convention should apply to de jure stateless persons only. A non-binding recommendation was included in the Final Act concerning de facto stateless persons, or those who technically have a nationality although it is not effective [see Robinson Commentary, supra note 6 at 11]. If the Contracting State recognizes as valid the reasons for which a person has renounced the protection of the State of which he or she is a national, the recommendation is to consider sympathetically the possibility of according to that person the benefits of the Convention. The drafters were working under the assumption that cases of de facto stateless persons who were not refugees would be unlikely to arise.

25. In practice, UNHCR has found that the problem of de facto statelessness is broader and more frequent than the drafters of the 1954 Convention had anticipated, and may include persons who have no claim to asylum, but who nonetheless are without an effective nationality or whose nationality cannot be definitively established. See C.A. Batchelor, "Statelessness and the Problem of Resolving Nationality Status" (1998) 10:1/2 IJRL 156.

26. See Article 1 of the Convention on Certain Questions relating to the Conflict of Nationality Laws, 179 L.N.T.S. 89, 99.

27. P. Weis, "The United Nations Convention on the Reduction of Statelessness, 1961" (October 1962) 11 ICLQ 1073-1096 at 1074.

28. Statement by the President of the Conference, Robinson Commentary, supra note 6 at 16.

29. C.A. Batchelor, supra note 25 at 174.

30. Ibid. at 171:

[T] he fact that an individual does fit the category of persons who, with reference to the law, is normally granted nationality does not mean that that particular person was granted such status, as there may always be exceptions to the legislation, variances between the written word and the implementation of the law, or inadvertent actions on the part of either the individual or the State which result in a failure to acquire nationality. Thus, consultations with the State concerned are imperative for verification of nationality status."

31. Robinson (Robinson Commentary, supra note 6 at 11), who observes that it is the lack of nationality which must be provable and proven.

32. A statement by the British representative to the Conference; see Robinson Commentary, supra note 6 at 16.

33. Ibid. at $16-17$.

34. Ibid. at 17.

35. Due regard for principles of data protection is in all cases relevant.

36. UNRWA's working definition of a "Palestinian refugee" has been refined since the early 1950s to read: "[Palestinian refugee] shall mean any person whose normal place of residence was Palestine during the period 1 June 1946 to 15 May 1948 and who lost both home and means of livelihood as a result of the 1948 conflict." Since 1967, UNRWA has also been authorized to assist certain other persons in addition to Palestinian refugees; see UNHCR, "Note on the Applicability of Article 1D of the 1951 Convention relating to the Status of Refugees to Palestinian Refugees." See also L. Takkenberg, The Status of Palestinian Refugees in International Law, (Oxford: Clarendon Press, 1998) at 77-83.

37. BverwG, 1C 18.90 of 21.1.1992, InfAuslR 92,161.

(C) Carol Batchelor, 2005. This open-access work is licensed under a Creative Commons Attribution-NonCommercial 4.0 International License, which permits use, reproduction and distribution in any medium for non-commercial purposes, provided the original author(s) are credited and the original publication in Refuge: Canada's Journal on Refugees is cited. 
38. Having the rights and obligations which are attached to the possession of the nationality of a country without actually having the nationality is, to some extent, an irreconcilable concept. By definition, if one does not have the same rights, including civil and political rights, as those accorded to nationals, and cannot be obliged to perform civil service such as in the military, then the rights and obligations will not be the same as those "attached to the possession of the nationality of a country." However, reading the article in the context of the 1954 Convention suggests the interpretation outlined above, that provided a person is accorded basic rights normally reserved to nationals, and that these rights exceed those outlined in the 1954 Convention, then it would not be necessary in principle to apply the Convention in such cases. As an aside, the phrase should not be confused with differences in treatment as between nationals. In the latter case, while some nationals may have more rights than others, all of the persons concerned are still nationals. As such, these differences are technically not relevant to the 1954 Convention which is concerned only with cases of statelessness (although they may be of concern with regard to de facto statelessness). See P. Weis, "Statelessness as a Legal-Political Problem" in The Problem of Statelessness (British Section of the World Jewish Congress, July 1944), and C. Batchelor, supra note 25 at 159, footnote 5.

39. European Convention for the Protection of Human Rights and Fundamental Freedoms, 1950, Eur. T.S. No.5.

40. Convention against Torture and Other Cruel, Inhuman or Degrading Treatment or Punishment, 1984, U.N.T.S.

41. Real Decreto $N^{o} 865 / 2001$, de 20 de julio, por el que se aprueba el Reglamento de Reconocimiento del Estatuto de Apátrida [Royal Decree 865/2001 of 20 July approving the Regulation for the Recognition of the Status of Stateless Persons].

42. Bilateral agreements relating to social security matters concluded by Austria refer to the 1954 Convention Definition. This is, for instance, the case for Article 3 of the "Abkommen über Soziale Sicherheit mit Dänemark” (Agreement on Social Security with Denmark of 1998). Similarly, the Final Protocol between Austria and Germany on insurance for unemployment benefits (Schlussprotokoll zu dem Abkommen zwischen Österreich und Deutschland über Arbeitslosenversicherung) of 1979 also refers to the 1954 Convention Definition: “ $\mathrm{Zu}(\ldots)$ Staatenlosen im Sinne des Artikels 3 (Anm. des Arbeitslosenversicherungsabkommens) gehören (...) Staatenlose im Sinne des Artikels 1 des Übereinkommens vom 28. September 1954 über die Rechtstellung der Staatenlosen”. [“... stateless persons within the meaning of Article 3 (of the Agreement on insurance for unemployment benefits) include ... stateless persons within the meaning of Article 1 of the Convention of 28 September 1954 relating to the Status of Stateless Persons"].

43. Germany and Italy, for example.

44. Ireland and the United Kingdom for example, although the United Kingdom does, nonetheless, have provisions to issue 1954 Convention Travel Documents.

45. Supra note 41.
46. See the Web site of the OFPRA, online: <http://www.ofpra. gouv.fr.htlm>.

47. Article 17 of D.P.R. 12 October 1993, No. 572, Regolamento di esecuzione della legge 5 febbraio 1992, n. 91, recante nuove norme sulla cittadinanza [Implementing Regulation to the Law of 5 February 1992, No. 91, including new provisions on citizenship]; hereinafter DPR 572/93.

48. In Luxembourg, jurisdiction over stateless persons appears to rest with the Ministry of Foreign Affairs, which is responsible for the issuance of 1954 CTDs.

49. It appears that this is the practice in Denmark, Finland, Greece, Ireland, Sweden, the United Kingdom, the Netherlands, and Portugal.

50. Article 8(3) of the Regulation for the Recognition of the Status of Stateless.

51. Article 57/6 of Loi du 15 décembre 1980 sur l'accès au territoire, le séjour, l'établissement et l'éloignement des étrangers (Moniteur Belge 31 décembre 1980).

52. For example, in Greece, the Ministry of Public Order; in Finland, the Directorate of Immigration within the Ministry of Interior; in Sweden, the Immigration Board; and in Britain, the Immigration and Nationality Directorate within the Home Office.

53. In Germany, for example, as noted it is the local aliens' authorities who make decisions. In addition to being widely dispersed, they may not have access to country-of-origin information, such as that which is at the disposal of the authorities dealing with asylum claims.

54. This would not, however, alter the fact of statelessness if indeed a person is not considered a national by any State under the operation of its law.

55. See Article 5 of Real Decreto $N^{o} 865 / 2001$, Spain's Regulation for the Recognition of the Status of Stateless Persons, supra note 41; in Italy, see the Protocol of the Ministry of Interior 300/C/2003/996/P/15.8.1/1a Div. Direzione Centrale.

56. The Brussels Court of Appeal, 4 May 1999. A summary of the Décision is found at (1999) 103 Revue du Droit des étrangers at 243:

[l'appelant] soutient dès lors à très juste titre que dans l'attente d'une décision concernant la reconnaissance de la qualité d'apatride, il se voit dans l'impossibilité d'exécuter l’ordre de quitter le territoire qui lui a été décerné, faute de connaître le pays qui pourrait l'accueillir, et qu'il se trouve condamné à vivre dans l'illégalité et la clandestinité, en Belgique ou ailleurs, avec le risque toujours présent, d'être arrêté, refoulé ou détenu à cette fin (...) sans possibilité d'aller et venir librement ni pourvoir légalement à sa propre subsistance (...) La Commission européenne des droits de l'homme a appliqué cette notion de traitement inhumain et dégradant à la situation des réfugiés dits "sur orbite ", c'est à dire condamnés à errer d'un État à l'autre à la recherche d'une terre d'accueil (...) La Cour estime qu'en l'occurrence, la situation de l'appelant est assimilable à celle d'un "réfugié sur orbite ", et qu'en étant contraint de vivre dans l'illégalité et la clandestinité, sans ressources ni moyens de s'en procurer

(C) Carol Batchelor, 2005. This open-access work is licensed under a Creative Commons Attribution-NonCommercial 4.0 International License, which permits use, reproduction and distribution in any medium for non-commercial purposes, provided the original author(s) are credited and the original publication in Refuge: Canada's Journal on Refugees is cited. 
(...) l'appelant qui, prima facie peut se voir reconnaître la qualité d'apatride, se trouve soumis à un traitement dégradant au sens de l'article 3 CEDH.

57. The European Convention on Human Rights and Fundamental Freedoms [ECHR], Eur. T.S. No. 5.

58. Supra note 46.

59. Spain's Real Decreto $N^{o} 865 / 2001$, supra note 41 , sets out specific provisions for minors who are in the statelessness procedure. If declared to be in a vulnerable situation, the child will be given to Minor Protection Services. During the procedure, the minor's residence in Spain will be authorized and a public guardian will represent the child's interests.

60. This category would not include those stateless persons entering to seek asylum. See Article 31 of the 1951 Refugee Convention.

61. This does not mean to say that a Contracting State is limited to this framework should they wish to provide more extensive entitlements. Article 5 stipulates that: "Nothing in this Convention shall be deemed to impact any rights and benefits granted by a Contracting State to stateless persons apart from this Convention." Moreover, an assessment of what is practically possible for a stateless person would reveal that it is difficult to request a visa for lawful entry if an individual has no identity or travel document to submit to authorities.

62. Article 31 of the 1951 Refugee Convention provides:

The Contracting States shall not impose penalties, on account of their illegal entry or presence, on refugees who, coming directly from a territory where their life or freedom was threatened in the sense of Article 1, enter or are present in their territory without authorization, provided they present themselves without delay to the authorities and show good cause for their illegal entry or presence.

63. It should be noted that in certain instances, stateless persons will be presumed to be lawfully present in a State. For example, in the case of State succession, should persons who were nationals of the predecessor State find themselves, following the succession, living on the territory of a successor State although they themselves have not changed place of residence, there would be a legal presumption of lawful stay unless treaties or other laws compatible with international legal norms specifically regulate otherwise. Moreover, it should be recalled that the 1954 Convention is addressing cases of statelessness which the Contracting State has not itselfcreated. If the Contracting State has denationalized or otherwise rendered someone stateless, the appropriate legal reference point is the 1961 Convention on the Reduction of Statelessness.

64. As earlier noted, UNHCR can advise on approaches to these cases and can assist in consultations in appropriate instances.

65. Paragraph 13(1) of the Schedule to the 1954 Convention.

66. For France, see Article 12bis (10) of the Ordonnance $n^{\circ} 45-2658$ du 2 novembre 1945 relative aux conditions d'entrée et de séjour des étrangers en France; for Italy, see Article 11(1)(c) of D.P.R. No. 394 of 31 August 1999; and for Spain, see Article 34 of the Aliens' Law 4/2000 as amended by 8/2000, Article 13 of the
Real Decreto $N^{\circ} 865 / 2001$, and Article 42 of the Implementing Decree to the Aliens' Law.

67. This appears to be the case in Ireland, Sweden, Denmark, Finland, and the UK. For example, in Denmark, legislation does not contain a specific provision providing permission to stay for stateless persons. Thus, a stateless person can remain in Denmark only if granted permission to stay within existing provisions of the Aliens' (Consolidated) Act; that is, if recognized to be a refugee within the provisions of the 1951 Convention, as provided for in Article 7(1); to risk receiving the death penalty or being subject to torture or inhuman or degrading treatment or punishment if returned to the country of origin as provided for in Article 7(2); or to be granted a residence permit if found to be "in such a position that essential considerations of a humanitarian nature conclusively make it appropriate to grant the application" under Article 9 (b) (1).

68. For example, in the Netherlands and Germany.

69. Stateless persons may apply for permanent residence under the general section of the Aliens' legislation; that is, Section 9 of LD 286/1998. This section prescribes that foreigners who have lawfully resided in Italy for at least six years and hold a residence permit issued for a reason which allows an indefinite number of renewals, and who demonstrate that their income is sufficient to support themselves and their families, may apply for permanent residence for themselves, their spouse and children. Permanent residence is granted for an unlimited period. Act No. 91 of 5 February 1992, pertaining to nationality matters, states in Article 16 that: "A stateless person who is legally resident in the territory of the Republic is subject to Italian law as far as the exercise of civil rights and the obligation to perform military service are concerned."

70. Article 12 bis paragraph 10, Ordonnance $\mathrm{n}^{\mathrm{o}} 45-2658 \mathrm{du} 2$ novembre 1945 (relative aux conditions d'entrée et de séjour des étrangers en France).

71. Article 15, paragraph 11 , Ordonnance ${ }^{\circ} 45-2658$ du 2 novembre 1945. NB: This is about to change in France; the three-year period is going to be increased to five years for foreigners, including stateless persons, who fall into this group. Refugees have a different set of rights, with automatic acquisition of permanent residence.

72. In Ireland, you must be legally resident for five years before being able to apply for long-term residence. In France, after three years of having a carte de séjour, you can receive the carte de résidence. French legislation is about to be amended to a five-year period.

73. See online: <http://europa.eu.int/rapid/start/cgi/guesten>. Notably, the EU Commission is beginning work on a separate proposal which would include refugees and those with subsidiary forms of protection. Harmonization with regard to stateless persons would be usefully reviewed in these undertakings.

74. See, for example, section 30(3) of the German Act Concerning the Entry and Residence of Aliens in the Territory of the Federal Republic (Aliens'Act) of 1 January 1991, which holds that:

(C) Carol Batchelor, 2005. This open-access work is licensed under a Creative Commons Attribution-NonCommercial 4.0 International License, which permits use, reproduction and distribution in any medium for non-commercial purposes, provided the original author(s) are credited and the original publication in Refuge: Canada's Journal on Refugees is cited. 
An alien who has received a final order to leave the country may be issued with a residence authorization, notwithstanding the provisions of sections 8 , para.1, if the conditions prescribed in section 55, para.2, for the grant of a temporary consent are met, where for reasons beyond his control he cannot leave voluntarily and cannot be deported.

Section 55(2) prescribes that: "An alien will be granted a temporary consent to remain as long as his expulsion is impossible on legal or factual grounds, or has to be stayed pursuant to section 53 , para.6, or section 54."

75. Section 30(4) of the German Aliens' Act holds that:

In other instances an alien who has been under a final order to leave for at least two years, and who holds a temporary consent, notwithstanding the provisions of section 8 , paras. 1 and 2, may be issued with a residence authorization, unless the alien refuses to comply with reasonable requests for the removal of the bar to deportation.

76. Belgium, for example: Loi du 22 décembre 1999 relative à la régularisation de séjour de certaines catégories d'étrangers séjournant sur le territoire du Royaume (M.B. 10 janv. 2000).

77. Again, with reference to Article 5, there is no bar to extending rights exceeding the level outlined in the Convention should a State wish to do so.

78. International Covenant on Civil and Political Rights [ICCPR], U.N.T.S. 1966.

79. See Article 1 of the ECHR.

80. Article 18 of the ICCPR; Article 9 of the ECHR.

81. Robinson Commentary, supra note 6 at 34-35.

82. Universal Declaration of Human Rights, U.N.T.S., 1949.

83. See also Article 11 of the ECHR; Article 20, UDHR; Article 22 of the ICCPR.

84. See also Articles 2 and 14 of the ICCPR.

85. Robinson Commentary, supra note 6 at 62; and also P. Weis, The Refugee Convention, 1951 (Cambridge: Cambridge University Press, 1995) at 147-48.

86. Robinson Commentary, supra note 6 at 67 ; and also P. Weis, The Refugee Convention, 1951, supra note 85.

87. Section 40(4) of Italy's LD 286/98:

Legally resident foreigners may obtain access to social, collective or private housing provided in accordance with the criteria laid down in regional legislation by the municipalities with the largest foreign populations, voluntary associations, foundations or organisations or other public or private agencies in the ambit of accommodation structures, mainly organised in the form of hostels, open to Italians and foreigners alike, which are designed to offer decent accommodation on payment of a subsidised price until permanent ordinary housing can be obtained.

88. Article 28 of the Convention of the Rights of the Child, (U.N.T.S. 1989) requires States to make primary education compulsory and available free to all. See also Article 26 of the UDHR, Article 2 of Protocol No. 1 of the ECHR, and Article 13 of the
International Covenant on Economic, Social and Cultural Rights, U.N.T.S. 1966.

89. In Belgium, education is compulsory until 18 and even illegal aliens must attend. Free access until 18 is guaranteed in several states, including Luxembourg and the UK; see UNHCR, "Reception Standards for Asylum Seekers in the European Union," July 2000, 15. In Italy, school attendance is compulsory for foreign minors present in Italy; see Section 38(1) of the Consolidated Immigration and Foreigners' Act, Legislative Decree No. 286/1998, as amended by Laws No. 182/2002 and 106/2002 and by Presidential Decree No. 115/2002.

90. According to Section 27 of the German Aliens' Law, to obtain indefinite residence, which is possible after eight years of temporary residence, you must not be dependent on social aid.

91. Legislative Decree 286/98, Section 41(1).

92. Ibid.; also Weis, The Refugee Convention, 1951, supra note 85.

93. In Spain, the Office for Asylum and Refuge (Art. 13(3) of the Real Decreto $N^{\circ}$ 865/2001); in France, the OFPRA (Art 4 of the Loi $\mathrm{n}^{\circ}$ 52-893 du 25 juillet 1952 relative au droit d'asile); in Belgium, the Commissariat Général aux réfugiés et aux apatrides (Article 57/6 of Loi du 15 décembre 1980 sur l'accès au territoire, le séjour, l'établissement et l'éloignement des étrangers).

94. Germany.

95. Refugees and those with temporary leave to remain are issued cards with "Stamp No. 4."

96. Paragraph 13 of the Schedule to the 1954 Convention. If the Contracting State specifies return within a period shorter than the validity of the CTD, it must be at least three months unless the State to which the individual intends to travel does not insist on the travel document according the right of return.

97. Article 13.2 of Spain's Real Decreto $N^{o} 865 / 2001$ prescribes that the recognized stateless person will be issued with the travel document foreseen in Article 28 of the 1954 Convention; according to Section 10 of Sweden's Aliens' Ordinance (1989:547): "A travel document shall be issued in cases referred to in the Convention of 28th July 1951 Relating to the Status of Refugees or the Convention of $28^{\text {th }}$ September 1954 Relating to the Status of Stateless Persons, or the Convention of $23^{\text {rd }}$ November 1957 Relating to Refugees who are Seamen." In Portugal, Article 20 of Legislative Decree 264-C/1981, containing provisions governing entry, stay, and departure of aliens and their expulsion from Portuguese territory, stipulates that an alien's passport may be granted to the following persons: a person who, being a resident in Portuguese territory, is stateless or is the national of a country without diplomatic or consular representation in Portugal or who demonstrates his inability to obtain another passport. In Finland, an alien's passport could be issued, a question determined by the Directorate of Immigration. Section 5(1) of Finland's Aliens' Act allows the Directorate to issue the travel document to an alien who is resident in Finland if he is unable to obtain a passport from the authorities of his country of origin or should there be other special grounds for doing so.

98. For example, France, Germany, Greece, Italy, and the United Kingdom.

(C) Carol Batchelor, 2005. This open-access work is licensed under a Creative Commons Attribution-NonCommercial 4.0 International License, which permits use, reproduction and distribution in any medium for non-commercial purposes, provided the original author(s) are credited and the original publication in Refuge: Canada's Journal on Refugees is cited. 
99. AuslG1990DV

100. BverwG 1 C 30.93 of 16.7.1996, InfAuslR 97, 58. If the stateless person has a residence permit in Germany, and not merely a toleration permit, then CTDs are regularly issued. If the applicant does not have a residence permit, then the CTD is difficult to obtain, particularly if the applicant voluntarily renounced nationality or has tried to acquire a travel document from another country.

101. Article 76(1) of the Austrian Aliens' Act states that when it is in the interest of the Republic, an alien's passport (Fremdenpasse) may be issued, upon application, to a stateless person whose nationality is unclear and who does not possess a valid travel document. Italy issues a CTD to de jure stateless persons by direct application of the 1954 Convention, while de facto stateless persons may be issued with an Alien's Travel Document. Both Denmark and Finland provide that the Minister may issue an Alien's travel document to a resident foreigner who is unable to obtain a passport from the country of origin or when there are other special grounds for doing so; see Article 39(5) of the Danish Aliens' (Consolidated) Act No. 608 of 17 July 2002 and Section 5(1) of Finland's Aliens' Act of March 1991.

102. CTDs issued in Spain and Italy are issued for a period of two years. The Aliens' Ordinance of Sweden stipulates that the Swedish Immigration Board shall issue a travel document to cases referred to in the 1954 Convention relating to the Status of Stateless Persons for a certain period. Finland, for example, can issue an alien's passport for a maximum of ten years. In Austria, an alien's passport can be issued for a period of five years, or shorter if appropriate.

103. Robinson Commentary, supra note 6 at 94-95.

104. Ibid. at 48; see also P. Weis, supra note 85 at 84 .

105. Ibid.; see also Robinson Commentary, supra note 6 at 64 .

106. Ibid. at 98 .

107. See Legge 1 Febbraio 1962 n.306 - Ratifica ed esecuzione della convenzione relativa allo status degli apolidi adottata a New York il 28 settembre 1954. The consolidated LD 286/1998 provides in Section 9(5) that:

Administrative deportation of the holder of a permanent residence card may only be ordered for serious reasons of public order or national security or if the holder belongs to one of the categories specified in section 1 of Statute no. 1423 of 27 December 1956, as replaced by section 2 of Statute no. 327 of 3 August 1988, or in section 1 of Statue no. 527 of 31 May 1965, as replaced by section 13 of Statute no. 646 of 13 September 1982, provided that one of the measures referred to in section 14 of Statute no. 55 of 19 March 1990 is applied, even on a precautionary basis.

Stateless persons are currently eligible to apply for permanent residence after six years, like other foreigners legally residing in Italy.

108. Facilitated naturalization of lawfully and habitually resident stateless persons is also provided for in the 1997 European
Convention on Nationality, relevant in certain of the EU Member States.

109. In Belgium, stateless persons may naturalize after two years instead of three for regular foreigners (Article 19 of the Belgian Code of Nationality); in Germany, naturalization of stateless persons is possible after six years instead of eight (Administrative Guidelines to the Law on Nationality). Denmark requires nine years of residence, but it is possible for stateless persons to naturalize after eight (see Danish Ministry for Refugees, Immigration and Integration Affairs Web site, online: $<$ http://www/inm.dk) $>$. Greek legislation allows a stateless person to naturalize after five years instead of ten [Article 58, para. 2(a) of Law 2910 (Aliens' Law)]. Italian law permits naturalization of stateless persons after five years instead of ten (Article 9(e) of Act No. 91). In Sweden, stateless persons may apply to naturalize after four years of residence instead of five (Section 11 of the Citizenship Act of 1 July 2001). Finland has recently amended its Nationality Act, which now includes facilitating naturalization for stateless persons. According to information obtained on the Directorate of Immigration Web site, the amended Nationality Act, which came into effect on 1 June 2003, prescribes that the normal residence period for naturalization is six years. However, if "you have refugee status in Finland or a residence permit based on your need for protection or you are stateless against your will, the required period of residence is: the last four years without interruption; or a total of six year since your $15^{\text {th }}$ birthday, with the last two years without interruption. See online: $<$ http://www/uvi.fi $>$.

110. Section $16(\mathrm{~g})$ of the Irish Nationality and Citizenship Act, 1956, No. 26 of 1956, as amended by the Irish Nationality and Citizenship Act 2001 (No. 15 of 2001) holds that:

The Minister may, in his absolute discretion, grant an application for a certificate of naturalisation in the following cases, although the conditions for naturalisation (or any of them) are not complied with: (g) where the applicant is a person who is a refugee within the meaning of the United Nations Convention relating to the Status of Refugees of the $28^{\text {th }}$ day of July, 1951, and the Protocol relating to the Status of Refugees of the $31^{\text {st }}$ day of January, 1967, or is a stateless person within the meaning of the United Nations Convention relating to the Status of Stateless Persons of the $28^{\text {th }}$ day of September, 1954.'

111. Robinson Commentary, supra note 6 at 102.

112. The main implementing decree to Spain's Aliens' Act (Real Decreto $\mathrm{N}^{\mathrm{o}} 864 / 2001$, de 20 de julio, por el que se aprueba el Reglamento de Ejecución de la Ley Orgánica 4/2000 sobre derechos y libertades de los extranjeros en España y su integración social, reformada por la Ley Orgánica 8/2000) holds in Article 145 that, in order to implement the objectives of the social integration of aliens, the Ministry of Labour and Social Affairs will set up a public network of Migration Centres to carry out functions of assistance, reception, social intervention, and if necessary appropriate counselling of aliens under asylum-seeker status, displaced status, refugees 
and stateless persons or of immigrants in vulnerable situations or who are under risk of social exclusion. Section 40(1) of Italy's LD 286/1998 prescribes that: "Regional councils, in liaison with provincial and municipal councils and voluntary associations and organisations, will set up reception centres designed to accommodate foreigners who are legally resident for reasons other than tourism and are temporarily unable to provide for their own accommodation and subsistence...". Section 40 (1bis) of the same Act provides that "Access to social integration measures is reserved for foreigners who do not belong to European Union countries and prove that they have complied with the provisions governing residence in Italy contained in this Consolidated Act and with the current legislation and regulations on the subject."

113. Article 14 of the Regulation for the Recognition of the Status of Stateless Persons prescribes that "stateless persons are entitled to request family reunification with the family members mentioned in Art. 17.1 of the Aliens' Law." Article 17.1 describes those family members, such as spouse, unmarried children under 18 or unmarried disabled children and dependent parents. Article 18 of the Aliens' Act contains stipulations to be met before family reunification can take place, such as adequate housing and sufficient means of support.

114. Section 29(3) of Italy's LD 286/1998.

115. Moreover, refusal of a Contracting State to allow an individual, admitted only temporarily on the travel document of another Contracting State, to prolong stay beyond the period provided for, was not considered by the drafters to constitute expulsion.
Carol Batchelor, B.A. (University of Washington), J.D. (Stanford University), LL.M. (Cambridge University), is currently Deputy Chief of Mission, Office of the UNHCR Chargé de Mission in India. From 1994 to 2004, she was the Senior Legal Officer Statelessness for the United Nations High Commissioner for Refugees, guiding developments concerning UNHCR's role and activities on statelessness while spearheading global operations in this field.

(C) Carol Batchelor, 2005. This open-access work is licensed under a Creative Commons Attribution-NonCommercial 4.0 International License, which permits use, reproduction and distribution in any medium for non-commercial purposes, provided the original author(s) are credited and the original publication in Refuge: Canada's Journal on Refugees is cited. 